\title{
The IMPACTT Model: Structure and Technical Description
}

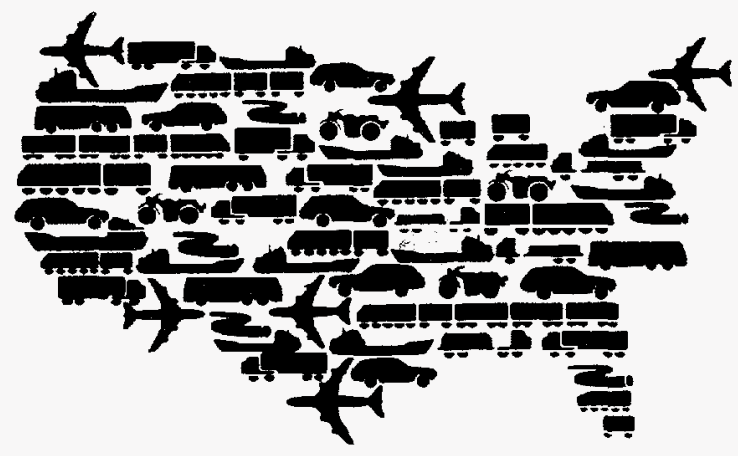

Center for Transportation Research Argonne National Laboratory 


\section{Argonne National Laboratory}

Argonne National Laboratory, with facilities in the states of Illinois and Idaho, is owned by the United States Government, and operated by the University of Chicago under the provisions of a contract with the Department of Energy.

This technical memo is a product of Argonne's Energy Systems (ES) Division. For information on the division's scientific and engineering activities, contact:

Director, Energy Systems Division

Argonne National Laboratory

Argonne, illinois 60439-4815

Telephone (708) 252-3724

Presented in this technical memo are preliminary results of ongoing work or work that is more limited in scope and depth than that described in formal reports issued by the ES Division.

Publishing support services were provided by Argonne's Information and Publishing Division.

\section{Disclaimer}

This report was prepared as an account of work sponsored by an agency of the United States Government. Neither the United States Government nor any agency thereof, nor any of their employees, makes any warranty, express or implied, or assumes any legal liability or responsibility for the accuracy, completeness, or usefulness of any information, apparatus, product, or process disclosed, or represents that its use would not infringe privately owned rights. Reference herein to any specific commercial product, process, or service by trade name, trademark, manufacturer, or otherwise, does not necessarily constitute or imply its endorsement, recommendation, or favoring by the United States Government or any agency thereof. The views and opinions of authors expressed herein do not necessarily state or reflect those of the United States Government or any agency thereof.

Reproduced directly from the best available copy.

Available to $D O E$ and $D O E$ contractors from the Office of Scientific and Technical Information, P.O. Box 62, Oak Ridge, TN 37831; prices available from (615) 576-8401.

Available to the public from the National Technical Information Service, U.S. Department of Commerce, 5285 Port Royal Road, Springfield, VA 22161. 


\section{DISCLAIMER}

Portions of this document may be illegible in electronic image products. Images are produced from the best available original document. 


\section{The IMPACTT Model: Structure and Technical Description}

M.M. Mintz, M.M. Tompkins, ${ }^{*}$ and J. Camp*

Center for Transportation Research, Energy Systems Division,

Argonne National Laboratory, 9700 South Cass Avenue, Argonne, Illinois 60439

December 1994

Work sponsored by United States Department of Energy,

Office of Transportation Technologies DISTRIBUTION OF THIS DOCUMENT IS UNLIMITED

\footnotetext{
‘Tompkins and Camp are affiliated with Argonne's Decision and Information Sciences Division.
}

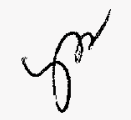


ब田

This report is printed on recycled paper. 


\section{CONTENTS}

AVAILABILITY OF COMPUTER SOFTWARE $\ldots \ldots \ldots \ldots \ldots \ldots \ldots \ldots$

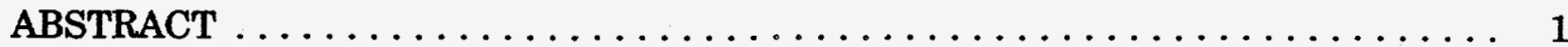

1 INTRODUCTION AND OVERVIEW $\ldots \ldots \ldots \ldots \ldots \ldots \ldots \ldots \ldots$

2 METHODOLOGY $\ldots \ldots \ldots \ldots \ldots \ldots \ldots \ldots \ldots \ldots \ldots \ldots \ldots \ldots$

2.1 General Worksheets $\ldots \ldots \ldots \ldots \ldots \ldots \ldots \ldots \ldots \ldots \ldots \ldots \ldots \ldots$

2.2 Technology-Specific Worksheets $\ldots \ldots \ldots \ldots \ldots \ldots \ldots \ldots \ldots \ldots \ldots \ldots \ldots$

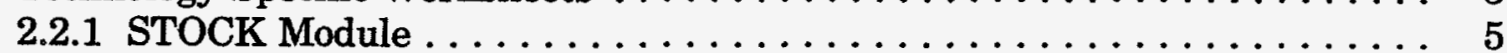

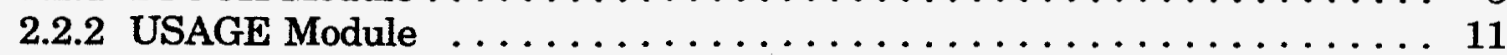

2.2 .3 EMISSIONS Module $\ldots \ldots \ldots \ldots \ldots \ldots \ldots \ldots \ldots \ldots \ldots$

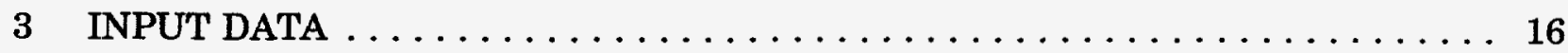

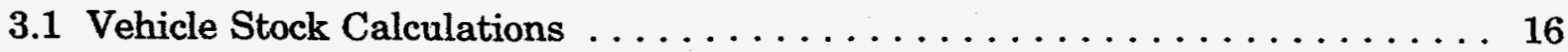

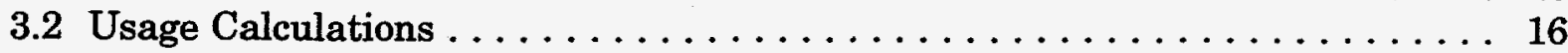

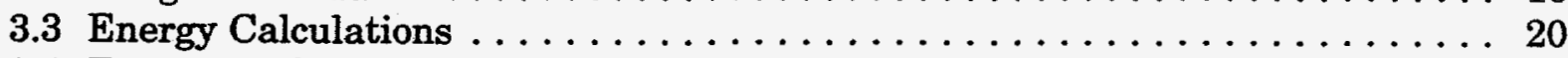

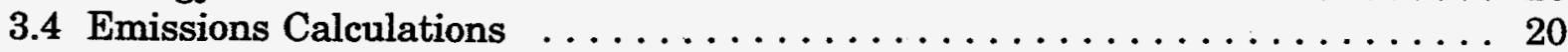

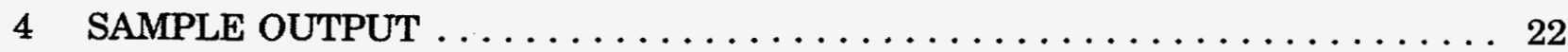

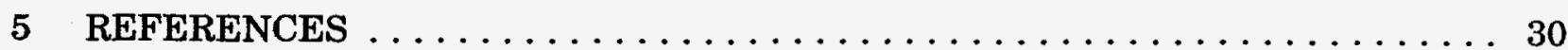

APPENDIX: $"$ READ ME" FLLE $\ldots \ldots \ldots \ldots \ldots \ldots \ldots \ldots \ldots \ldots \ldots \ldots \ldots$

TABLES

1 Workbook Organization $\ldots \ldots \ldots \ldots \ldots \ldots \ldots \ldots \ldots \ldots \ldots \ldots$

2 Default New-Vehicle Sales by Vehicle Type $\ldots \ldots \ldots \ldots \ldots \ldots \ldots$

3 Default On-Road and EPA-Test Fuel Economy of New Light-Duty Vehicles . . . 7

4 Default Emission Rates of Automobiles by Age and Pollutant . . . . . . . . 8

5 Default Emission Rates of Light Trucks by Age and Pollutant .......... 9

6 Default Emission Rates of Total Light-Duty Vehicles by Age and Pollutant . . . 10

7 Default Market Penetration of Total Light-Duty Vehicles $\ldots \ldots \ldots \ldots \ldots$

8 Default Market Penetration of Medium and Heavy Trucks $\ldots \ldots \ldots \ldots \ldots$ 


\section{TABLES (Cont.)}

9 Default Annual Miles by Age and Vehicle Type $\ldots \ldots \ldots \ldots \ldots \ldots \ldots \ldots$

10 Default Gasoline-Equivalent Miles per Gallon of New Advanced-Technology, Light-Duty Vehicles .................. 21

11 Vehicle Miles Traveled by Advanced-Technology, Light-Duty Vehicles . . . . . . 23

12 Fuel Consumption of Light-Duty Vehicles by Fuel Type . . . . . . . . . . 24

13 Stocks of Light-Duty Vehicles and Share of Alternative-Fuel Vehicles . . . . . 25

14 Total Emissions Reduction from Seven Advanced Technologies . . . . . . . . 26

15 Total Light-Duty Vehicle Emissions from All Advanced and Conventional Technologies . . . . . . . . . . . . . . . . . . 27

16 Oil Displacement by Light-Duty Vehicle Technology . . . . . . . . . . . . 28

17 Baseline Oil Consumed and Displaced by All Advanced Technologies . . . . . . 29

\section{FIGURE}

1 Structure of IMPACTT Technology-Specific Worksheets $\ldots \ldots \ldots \ldots \ldots \ldots$ 
This computer software has been developed under the sponsorship of the United States Department of Energy (DOE). Any further distribution by any holder of the software package or other data therein outside of DOE offices or other DOE contractors, unless otherwise specifically provided for, is prohibited without the approval of the Energy Science and Technology Software Center. Requests from outside the Department of Energy for DOEdeveloped computer software shall be directed to Energy Science and Technology Software Center, P.O. Box 1020, Oak Ridge, TN 37831-1020; telephone: (615) 576-2606. 


\title{
THE IMPACTT MODEL: STRUCTURE AND TECHNICAL DESCRIPTION
}

by

M.M. Mintz, M.M. Tompkins, and J. Camp

\begin{abstract}
The Integrated Market Penetration and Anticipated Cost of Transportation Technologies model, or IMPACTT, is a spreadsheet model that calculates the effect of advanced-technology vehicles and market penetration on baseline fuel use and emissions. Outputs include estimates of the quantity and value of oil displaced and emissions reduced by advanced-technology vehicles, the quantity of alternative fuels they consume, and the total incremental costs borne by purchasers of advancedtechnology vehicles. In the current version of IMPACTT, up to eight fuel or engine technologies applicable to light-duty vehicles can be modeled by using a three-phase approach. First, the vehicle stock and miles traveled by the advanced-technology vehicle are determined. Second, assumptions about efficiency and fuel shares are used to estimate substitution-fuel use and oil displacement. Third, changes in emissions of carbon monoxide, nonmethane hydrocarbons, nitrogen oxides, and carbon dioxide are computed.
\end{abstract}

\section{INTRODUCTION AND OVERVIEW}

Argonne National Laboratory's (ANL's) Center for Transportation Research (CTR) developed the Integrated Market Penetration and Anticipated Cost of Transportation Technologies model (IMPACTT) to assist the U.S. Department of Energy's (DOE's) Office of Transportation Technologies (OTT) with program planning and development. IMPACTT is a spreadsheet model, operating in either an Apple ${ }^{\mathrm{TM}}$ or PC-compatible environment, that calculates the effect of advanced-technology vehicles and market penetration on baseline fuel use and emissions.

Outputs include estimates of the quantity and value of oil displaced and emissions reduced by advanced-technology vehicles, the quantity of alternative fuels they consume, and the total incremental costs borne by purchasers of advanced-technology vehicles. Estimates are based on exogenous projections of conventional vehicle sales, advanced-technology market penetration, and the characteristics of new conventional and advanced-technology vehicles. Vehicle characteristics include fuel efficiency; tailpipe emissions of nitrogen oxides $\left(\mathrm{NO}_{\mathrm{x}}\right)$, carbon monoxide (CO), and nonmethane hydrocarbons (NMHCs); and incremental capital cost 
(i.e., the unit cost of a conventional vehicle less the unit cost of an advanced-technology vehicle). Annual petroleum displacement and emissions reduction are calculated by projecting the miles traveled by each model year's conventional vehicles, their petroleum use, and their emissions and then subtracting those projections from comparable projections for advanced-technology vehicles. 


\section{METHODOLOGY}

Written in Microsoft EXCEL 5.0 workbook format, IMPACTT is a spreadsheet model consisting of eight general worksheets and an equal number of technology-specific worksheets, each of which represents a fuel or technology alternative. ${ }^{1}$ In addition to the 16 worksheets, a "Read Me" file (essentially an on-line, condensed version of this document; see Appendix A) is attached. The names and dimensions of the 16 worksheets are listed in Table 1.

As shown in Figure 1, IMPACTT's technology-specific worksheets contain three modules. The STOCK module projects the population or stock of an advanced- or conventional-technology vehicle from estimates of total vehicle sales, advanced-technology marginal cost and market penetration, and vehicle depreciation rates. The USAGE module then estimates the amount of substitution fuel consumed by the advanced-technology vehicle, as well as the vehicle-miles traveled (VMT), oil displaced, and carbon dioxide $\left(\mathrm{CO}_{2}\right)$ reduction achieved by that vehicle relative to a conventional-technology vehicle of the same age or model year. The EMISSIONS module then computes the quantity and dollar value of reductions in tailpipe and refinery emissions attributable to the advanced-technology vehicle. Finally, results are summarized across all technology-specific worksheets to yield total estimates of advanced-technology stocks, VMT, oil displacement, emissions reduction, and substitution-fuel use.

Several worksheets are needed to analyze the impacts of a portfolio of actual or proposed programs. For example, analyses of the DOE/OTT Diversified Strategy (U.S. DOE 1994a) required the use of eight technology-specific worksheets (corresponding to the following technologies and fuels: conventional internal-combustion engines [ICEs], advancedbattery electric, grid-connected hybrid, fuel cell, liquid petroleum gas (LPG), compressed natural gas (CNG), flexible-fuel ("flex-fuel") ethanol, and dedicated ethanol). Analyses of OTT's Advanced Hybrid Vehicle, Electric/Fuel Cell Vehicle, and Natural Gas Then Alcohol strategies required one, two, and three technology-specific worksheets, respectively.

\subsection{GENERAL WORKSHEETS}

The current version of IMPACTT contains eight general worksheets: INPUTS, SALES-MPG, EMIS INPUTS, VMT SUM, OIL SUM, EMIS SUM, CON SUM, and EMIS RED SUM. The INPUTS worksheet contains user-supplied forecasts of market penetration and marginal cost per vehicle for each advanced technology and an emissions rate for each of three criteria pollutants. The SALES-MPG worksheet contains forecasts of auto and light truck sales and fuel economy that are converted into weighted averages for input into the STOCK and USAGE modules. Default values from the SALES-MPG worksheet are listed in

1 Although all of the technologies included on the default file are targeted toward the class of total light-duty vehicles, separate analyses of autos and light-duty trucks may be performed by modifying internal pointers and output headings. 
TABLE 1 Workbook Organization

\begin{tabular}{lcc}
\hline \multicolumn{1}{c}{ Worksheet } & $\begin{array}{c}\text { Beginning } \\
\text { Cell Location }\end{array}$ & $\begin{array}{c}\text { Ending Cell } \\
\text { Location }\end{array}$ \\
\hline INPUTS & A-1 & S-54 \\
ICE & A-1 & BJ-75 \\
CNG & A-1 & BT-55 \\
LPG & A-1 & BT-55 \\
FLEX (ETOH) & A-1 & BT-62 \\
HYB (HYBRID) & A-1 & BT-60 \\
ELEC (EV) & A-1 & BT-62 \\
FCV (FUEL CELL) & A-1 & BT-60 \\
DED ETOH & A-1 & BT-60 \\
VMT SUM & A-1 & U-52 \\
CON SUM & A-1 & AW-53 \\
EMIS RED SUM & A-1 & AX-100 \\
EMIS INPUTS & A-1 & V-118D \\
EMIS SUM & A-1 & BO-100 \\
OIL SUM & A-1 & BK-53 \\
SALES-MPG & A-1 & M-45 \\
\hline
\end{tabular}

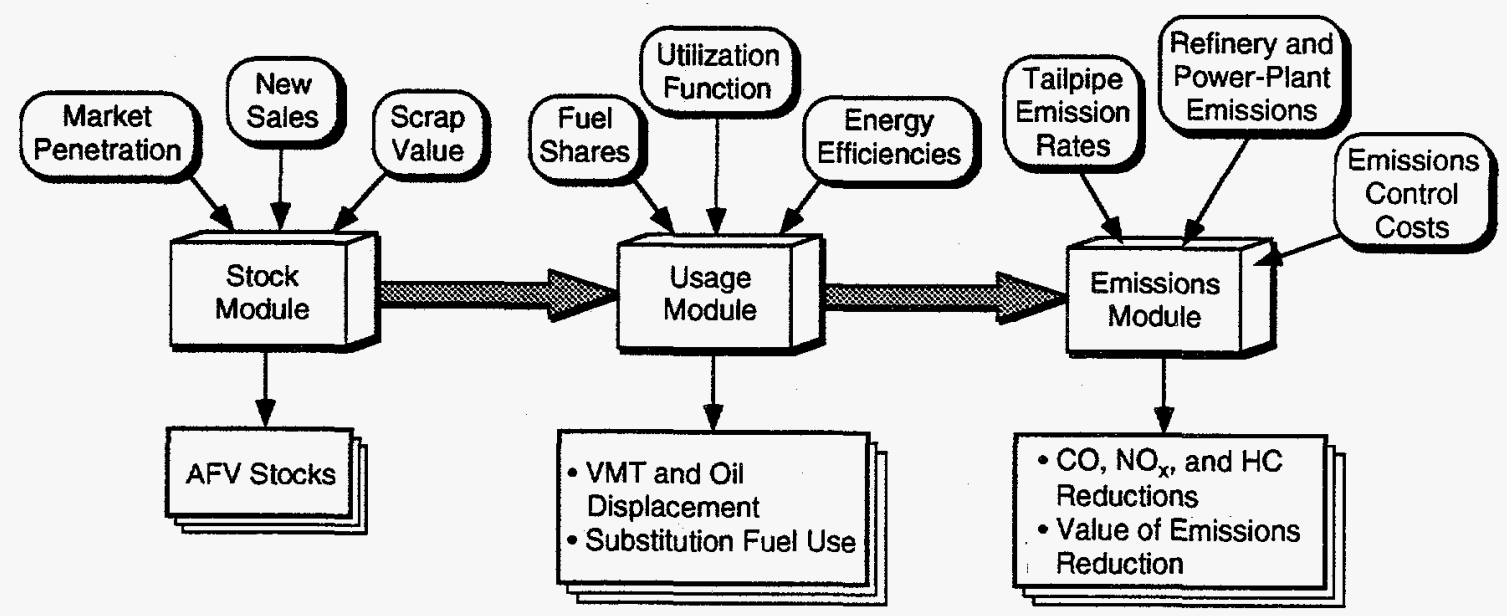

FIGURE 1 Structure of IMPACTT Technology-Specific Worksheets 
Tables 2 and 3. These forecasts were derived from the 1994 Annual Energy Outlook (DOE 1994b). Default values assume a $20 \%$ shortfall or gap between the U.S. Environmental Protection Agency's (EPA's) test results and on-the-road fuel economy (Mintz, Vyas, and Conley 1993).

The EMIS INPUTS worksheet contains (1) default rates of tailpipe emissions by vehicle type and vintage and (2) rates of refinery and power-plant emissions by fuel type. Expressed in grams per mile, rates were computed from the EPA's MOBILE5a model. Within EMIS INPUTS, values for total light-duty vehicles are weighted as $60 \%$ autos and $40 \%$ light trucks. Default values for power-plant emissions are based on the year 2000 electricity generation mix for New York City and southern California, the two locations likely to have the earliest market penetration of electric vehicles (EVs). Default values are weighted by the relative share of VMT contributed by each of these two markets (Wang and Santini 1994). Default values are provided in Tables 4-6.

Five summary worksheets aggregate results from the technology-specific worksheets. The VMT SUM worksheet summarizes fleet average miles-per-gallon (mpg) and vehicle-miles displaced by all advanced-technology vehicles, while OIL SUM and EMIS RED SUM summarize total oil displacement and emissions reduction. CON SUM summarizes substitution-fuel use (in physical units, quads ${ }^{2}$ and millions of barrels per day) and advancedtechnology vehicle stocks, while EMIS SUM summarizes emissions of criteria pollutants. Note that in both CON SUM and EMIS SUM, entries are aggregated over all technologies considered in the particular scenario under examination. Summary worksheets report annual results for 1990-2030 and cumulatively (as appropriate) for the periods 1990-2000, 1990-2010, 1990-2020, and 1990-2030.

\subsection{TECHNOLOGY-SPECIFIC WORKSHEETS}

The default case is based on the diversified scenario developed by the DOE's OTT for its five-year program plan. That scenario required the use of eight technology-specific worksheets. Thus, by using a common three-module framework, the default version of the model can accommodate up to seven advanced (and one conventional) technologies.

\subsubsection{STOCK Module}

The first and largest component of the technology-specific worksheets is the vehicle STOCK module. On the basis of a capital vintaging model developed by Greene and Rathi (1990), the module calculates the stock or population of conventional- or advanced-technology light-duty vehicles by forecast year. New-vehicle sales, market-penetration rates for advanced-technology vehicles, and scrap value are the key determinants of conventional-and

$210^{15}$ (one quadrillion) Btu $=1$ quad. 
TABLE 2 Default New-Vehicle Sales by Vehicle Type

\begin{tabular}{|c|c|c|c|c|}
\hline \multirow[b]{2}{*}{ Year } & \multicolumn{4}{|c|}{ Sales $\left(10^{3}\right)$ by Vehicle Type } \\
\hline & Autos & $\begin{array}{l}\text { Light } \\
\text { Trucks }\end{array}$ & $\begin{array}{c}\text { Medium } \\
\text { Trucks }\end{array}$ & $\begin{array}{l}\text { Heavy } \\
\text { Trucks }\end{array}$ \\
\hline 1990 & 9,580 & 4,390 & 160 & 110 \\
\hline 1991 & 8,450 & 3,930 & 130 & 90 \\
\hline 1992 & 8,420 & 4,500 & 140 & 100 \\
\hline 1993 & 9,060 & 5,110 & 170 & 120 \\
\hline 1994 & 9,420 & 5,310 & 190 & 140 \\
\hline 1995 & 9,290 & 5,330 & 210 & 150 \\
\hline 1996 & 9,540 & 5,180 & 216 & 154 \\
\hline 1997 & 9,740 & 5,300 & 222 & 158 \\
\hline 1998 & 9,790 & 5,450 & 228 & 162 \\
\hline 1999 & 9,780 & 5,550 & 234 & 166 \\
\hline 2000 & 9,780 & 5,660 & 240 & 170 \\
\hline 2001 & 9,760 & 5,770 & 248 & 174 \\
\hline 2002 & 9,780 & 5,920 & 256 & 178 \\
\hline 2003 & 9,840 & 6,120 & 264 & 182 \\
\hline 2004 & 9,990 & 6,230 & 272 & 186 \\
\hline 2005 & 10,120 & 6,270 & 280 & 190 \\
\hline 2006 & 10,230 & 6,260 & 288 & 192 \\
\hline 2007 & 10,480 & 6,360 & 296 & 194 \\
\hline 2008 & 10,490 & 6,390 & 304 & 196 \\
\hline 2009 & 10,410 & 6,410 & 312 & 198 \\
\hline 2010 & 10,370 & 6,520 & 320 & 200 \\
\hline 2011 & 10,421 & 6,572 & 328 & 202 \\
\hline 2012 & 10,524 & 6,676 & 336 & 204 \\
\hline 2013 & 10,575 & 6,728 & 344 & 206 \\
\hline 2014 & 10,626 & 6,780 & 352 & 208 \\
\hline 2015 & 10,677 & 6,832 & 360 & 210 \\
\hline 2016 & 10,729 & 6,884 & 368 & 212 \\
\hline 2017 & 10,780 & 6,936 & 376 & 214 \\
\hline 2018 & 10,831 & 6,988 & 384 & 216 \\
\hline 2019 & 10,882 & 7,040 & 392 & 218 \\
\hline 2020 & 10,934 & 7,092 & 400 & 220 \\
\hline 2021 & 10,985 & 7,144 & 400 & 220 \\
\hline 2022 & 11,036 & 7,196 & 400 & 220 \\
\hline 2023 & 11,087 & 7,248 & 400 & 220 \\
\hline 2024 & 11,139 & 7,300 & 400 & 220 \\
\hline 2025 & 11,190 & 7,352 & 400 & 220 \\
\hline 2026 & 11,241 & 7,404 & 400 & 220 \\
\hline 2027 & 11,292 & 7,456 & 400 & 220 \\
\hline 2028 & 11,343 & 7,508 & 400 & 220 \\
\hline 2029 & 11,395 & 7,560 & 400 & 220 \\
\hline 2030 & 11,446 & 7,612 & 400 & 220 \\
\hline
\end{tabular}

Sources: 1994-2010: DOE 1994b; post-2010: extrapolated. 
TABLE 3 Default On-Road and EPA-Test Fuel Economy of New Light-Duty Vehicles (mpg)

\begin{tabular}{|c|c|c|c|c|c|c|}
\hline \multirow[b]{2}{*}{ Year } & \multicolumn{2}{|c|}{ On-Road } & \multicolumn{2}{|c|}{ EPA Test } & \multicolumn{2}{|c|}{ Total Light Duty } \\
\hline & Auto & Light Truck & Auto & Light Truck & On-Road & EPA-Test \\
\hline 1990 & 22.56 & 16.73 & 28.20 & 20.91 & 20.33 & 25.42 \\
\hline 1991 & 22.50 & 16.76 & 28.13 & 20.95 & 20.29 & 25.36 \\
\hline 1992 & 22.44 & 16.78 & 28.05 & 20.98 & 20.08 & 25.10 \\
\hline 1993 & 22.59 & 16.93 & 28.23 & 21.16 & 20.16 & 25.19 \\
\hline 1994 & 22.73 & 17.07 & 28.41 & 21.34 & 20.30 & 25.38 \\
\hline 1995 & 22.88 & 17.21 & 28.59 & 21.52 & 20.43 & 25.53 \\
\hline 1996 & 23.02 & 17.36 & 28.78 & 21.70 & 20.65 & 25.81 \\
\hline 1997 & 23.17 & 17.50 & 28.96 & 21.87 & 20.79 & 25.99 \\
\hline 1998 & 23.31 & 17.64 & 29.14 & 22.05 & 20.91 & 26.13 \\
\hline 1999 & 23.46 & 17.79 & 29.32 & 22.23 & 21.03 & 26.28 \\
\hline 2000 & 23.60 & 17.93 & 29.50 & 22.41 & 21.15 & 26.43 \\
\hline 2001 & 23.78 & 18.08 & 29.72 & 22.60 & 21.29 & 26.61 \\
\hline 2002 & 23.95 & 18.24 & 29.94 & 22.80 & 21.42 & 26.78 \\
\hline 2003 & 24.13 & 18.39 & 30.16 & 22.99 & 21.55 & 26.94 \\
\hline 2004 & 24.30 & 18.55 & 30.38 & 23.19 & 21.72 & 27.15 \\
\hline 2005 & 24.48 & 18.70 & 30.60 & 23.38 & 21.89 & 27.37 \\
\hline 2006 & 24.61 & 18.83 & 30.76 & 23.54 & 22.04 & 27.55 \\
\hline 2007 & 24.74 & 18.95 & 30.92 & 23.69 & 22.18 & 27.73 \\
\hline 2008 & 24.87 & 19.08 & 31.09 & 23.85 & 22.31 & 27.88 \\
\hline 2009 & 25.00 & 19.20 & 31.25 & 24.00 & 22.42 & 28.02 \\
\hline 2010 & 25.13 & 25.13 & 31.41 & 24.16 & 22.52 & 28.15 \\
\hline 2011 & 25.13 & 19.33 & 31.41 & 24.16 & 22.52 & 28.14 \\
\hline 2012 & 25.13 & 19.33 & 31.41 & 24.16 & 22.51 & 28.13 \\
\hline 2013 & 25.13 & 19.33 & 31.41 & 24.16 & 22.50 & 28.13 \\
\hline 2014 & 25.13 & 19.33 & 31.41 & 24.16 & 22.50 & 28.12 \\
\hline 2015 & 25.13 & 19.33 & 31.41 & 24.16 & 22.49 & 28.12 \\
\hline 2016 & 25.13 & 19.33 & 31.41 & 24.16 & 22.49 & 28.11 \\
\hline 2017 & 25.13 & 19.33 & 31.41 & 24.16 & 22.49 & 28.11 \\
\hline 2018 & 25.13 & 19.33 & 31.41 & 24.16 & 22.48 & 28.10 \\
\hline 2019 & 25.13 & 19.33 & 31.41 & 24.16 & 22.48 & 28.10 \\
\hline 2020 & 25.13 & 19.33 & 31.41 & 24.16 & 22.47 & 28.09 \\
\hline 2021 & 25.13 & 19.33 & 31.41 & 24.16 & 22.47 & 28.09 \\
\hline 2022 & 25.13 & 19.33 & 31.41 & 24.16 & 22.47 & 28.08 \\
\hline 2023 & 25.13 & 19.33 & 31.41 & 24.16 & 22.46 & 28.08 \\
\hline 2024 & 25.13 & 19.33 & 31.41 & 24.16 & 22.46 & 28.07 \\
\hline 2025 & 25.13 & 19.33 & 31.41 & 24.16 & 22.46 & 28.07 \\
\hline 2026 & 25.13 & 19.33 & 31.41 & 24.16 & 22.45 & 28.07 \\
\hline 2027 & 25.13 & 19.33 & 31.41 & 24.16 & 22.45 & 28.06 \\
\hline 2028 & 25.13 & 19.33 & 31.41 & 24.16 & 22.45 & 28.06 \\
\hline 2029 & 25.13 & 19.33 & 31.41 & 24.16 & 22.44 & 28.05 \\
\hline 2030 & 25.13 & 19.33 & 31.41 & 24.16 & 22.44 & 28.05 \\
\hline
\end{tabular}

Sources: 1994-2010: DOE 1994b; post-2010: assumed constant. 
TABLE 4 Default Emission Rates of Automobiles by Age and Pollutant

\begin{tabular}{rrrrr}
\hline & \multicolumn{3}{c}{ Emission Rate by Pollutant (g/mi) } \\
\cline { 3 - 5 } Age & & & \multicolumn{2}{c}{ NMHCs } \\
\cline { 3 - 5 } (in years) & NO $_{x}$ & CO & Exhaust & Evaporative \\
\hline & & & & \\
$<1$ & 0.23 & 5.28 & 0.21 & 0.26 \\
1 & 0.31 & 7.00 & 0.28 & 0.26 \\
2 & 0.45 & 9.41 & 0.38 & 0.27 \\
3 & 0.58 & 11.63 & 0.48 & 0.28 \\
4 & 0.70 & 13.65 & 0.56 & 0.28 \\
5 & 0.97 & 18.24 & 0.88 & 0.39 \\
6 & 1.22 & 22.43 & 1.16 & 0.49 \\
7 & 0.05 & 26.36 & 1.43 & 0.58 \\
8 & 1.69 & 30.09 & 1.68 & 0.67 \\
9 & 1.91 & 33.42 & 1.91 & 0.76 \\
10 & 2.12 & 36.25 & 2.09 & 0.85 \\
11 & 2.31 & 39.47 & 2.31 & 0.93 \\
12 & 2.49 & 42.54 & 2.52 & 1.02 \\
13 & 2.66 & 45.43 & 2.72 & 1.10 \\
14 & 2.82 & 48.13 & 2.91 & 1.18 \\
15 & 2.98 & 50.71 & 3.09 & 1.30 \\
16 & 3.12 & 53.11 & 3.27 & 1.62 \\
17 & 3.26 & 55.35 & 3.45 & 1.79 \\
\hline
\end{tabular}

Source: EPA, MOBILE5a for post-2003 new vehicles. Because LPG, CNG, flex-fuel, and dedicated ethanol vehicles begin to appear before 2004, emission savings for those vehicles are somewhat understated.

advanced-technology vehicle stock in each forecast year. Comparable projections for heavyduty vehicles are produced within an earlier version of the model by applying historical survival and usage rates. Those calculations and inputs are not reported here.

In any given year, the equation for new (i.e., age $=0$ ) advanced-technology-vehicle stock is based on the market penetration for that technology as a share of total sales for light-duty vehicles (automobiles and light-duty trucks). A vintaging stock model is then used to estimate the number of vehicles in a given year by age.

For age $=0$,

$$
\mathrm{V}_{\mathrm{ij}}=S A L E S_{i} \times P_{i}
$$


TABLE 5 Default Emission Rates of Light Trucks by Age and Pollutant

\begin{tabular}{rrrrr}
\hline & \multicolumn{3}{c}{ Emission Rate by Pollutant $(\mathrm{g} / \mathrm{mi})$} \\
\cline { 3 - 5 } Age & & & \multicolumn{2}{c}{ NMHCs } \\
\cline { 3 - 5 } (in years) & $\mathrm{NO}_{\mathrm{x}}$ & $\mathrm{CO}$ & Exhaust & Evaporative \\
\hline & & & & \\
$<1$ & 0.44 & 8.25 & 0.28 & 0.24 \\
1 & 0.53 & 10.01 & 0.35 & 0.24 \\
2 & 0.68 & 12.61 & 0.45 & 0.25 \\
3 & 0.82 & 15.05 & 0.56 & 0.25 \\
4 & 0.98 & 18.02 & 0.71 & 0.28 \\
5 & 1.27 & 23.40 & 1.07 & 0.39 \\
6 & 1.55 & 28.41 & 1.39 & 0.50 \\
7 & 1.82 & 33.21 & 1.71 & 0.61 \\
8 & 2.09 & 37.85 & 2.01 & 0.71 \\
9 & 2.34 & 72.09 & 2.28 & 0.81 \\
10 & 2.59 & 45.83 & 2.52 & 0.91 \\
11 & 2.82 & 50.07 & 2.80 & 1.01 \\
12 & 3.03 & 54.10 & 3.07 & 1.10 \\
13 & 3.24 & 57.98 & 3.32 & 1.19 \\
14 & 3.44 & 61.69 & 3.57 & 1.28 \\
15 & 3.68 & 66.58 & 3.84 & 1.40 \\
16 & 3.93 & 69.47 & 4.10 & 1.67 \\
17 & 4.21 & 74.97 & 4.40 & 1.83 \\
\hline
\end{tabular}

Source: EPA, MOBILE5a.

For age $=2, \ldots, 17$,

$$
\mathrm{V}_{\mathrm{i} j}=V_{i-1, j-1} \times\left(1-\left[1+e^{A 0+M C_{i} \times A_{1} \times(1-D R A T E)}\right]^{-1}\right),
$$

where:

$$
\begin{array}{ll}
\mathrm{i} & =\text { year index, } 1990, \ldots, 2030 ; \\
\mathrm{j} & =\text { age index, } 0, \ldots, 17 \\
\mathrm{~V}_{\mathrm{ij}} & =\text { number of advanced-technology vehicles, year } \mathrm{i} \text { and age } \mathrm{j} ; \\
\text { SALES }_{\mathrm{i}} & =\text { vehicle sales, year } \mathrm{i} \\
\mathrm{P}_{\mathrm{i}} & =\text { market-penetration rate; } \\
\text { DRATE } & =\text { price-depreciation rate, generally set to } 0.15
\end{array}
$$


TABLE 6 Default Emission Rates of Total

Light-Duty Vehicles by Age and Pollutant

\begin{tabular}{rrrrr}
\hline & \multicolumn{3}{c}{ Emission Rate by Pollutant (g/mi) } \\
\cline { 3 - 5 } Age & & & \multicolumn{2}{c}{ NMHCs } \\
\cline { 3 - 5 } (in years) & NO $_{\mathbf{x}}$ & CO & Exhaust & Evaporative \\
\hline & & & & \\
$<1$ & 0.31 & 6.46 & 0.24 & 0.25 \\
1 & 0.40 & 8.20 & 0.31 & 0.25 \\
2 & 0.54 & 10.69 & 0.41 & 0.26 \\
3 & 0.67 & 13.00 & 0.51 & 0.27 \\
4 & 0.81 & 15.40 & 0.62 & 0.28 \\
5 & 1.09 & 20.30 & 0.95 & 0.39 \\
6 & 1.36 & 24.82 & 1.26 & 0.49 \\
7 & 0.76 & 29.10 & 1.54 & 0.59 \\
8 & 1.85 & 33.19 & 1.81 & 0.69 \\
9 & 2.08 & 48.89 & 2.06 & 0.78 \\
10 & 2.30 & 40.08 & 2.26 & 0.88 \\
11 & 2.51 & 43.71 & 2.51 & 0.97 \\
12 & 2.71 & 47.16 & 2.74 & 1.05 \\
13 & 2.89 & 50.45 & 2.96 & 1.14 \\
14 & 3.07 & 53.56 & 3.18 & 1.22 \\
15 & 3.26 & 57.06 & 3.39 & 1.34 \\
16 & 3.44 & 59.65 & 3.60 & 1.64 \\
17 & 3.64 & 63.20 & 3.83 & 1.81 \\
\hline
\end{tabular}

$\mathrm{MC}_{\mathrm{ij}}=$ marginal cost of a new advanced-technology vehicle divided by annual miles;

$\mathrm{A}_{0} \quad=$ asymptotic survival parameter; and

$\mathrm{A}_{1}=$ new-car scrappage parameter, $\mathrm{e}^{\mathrm{A} 1}$.

Equation 2 can be algebraically reformulated as:

$$
\mathrm{V}_{\mathrm{ij}}=V_{i-1, j-1}-\frac{V_{i-1, j-1}}{1+e^{A O+M C_{i} \times A_{1} \times(1-D R A T E)^{j}}} .
$$

The total number of advanced-technology vehicles in any year is then the summation across all ages of advanced-technology vehicles:

$$
\mathrm{V}_{\mathrm{i}}=\sum_{j} V_{i j}
$$




\subsubsection{USAGE Module}

The output of the STOCK module (vehicle stock by vintage for each advanced technology), an age-dependent utilization rate (annual VMT per vehicle), fuel shares, and energy efficiencies are the major inputs to the USAGE module. Vehicle-miles traveled, oil displacement, and substitution-fuel use for each advanced technology are the major outputs. ${ }^{3}$ Vehicle-miles traveled is computed as the sum of the product of total new-vehicle sales, advanced-technology market penetration, survival, and vehicle use by vintage. Potential oil displacement is computed as the sum of the product of VMT and conventional-vehicle mpg for each vintage. ${ }^{4}$ Displacement is reported in gallons and converted into millions of barrels per day (MMBD) and quads by using the assumptions of $42 \mathrm{gal} / \mathrm{bbl}$ and 115,400 Btu/gal (i.e., the lower heating value of gasoline). No conversion into barrels of imported oil is made within the model.

An advanced technology's impact on energy use includes both (1) the quantity of petroleum displaced by the use of the advanced-technology vehicle and (2) the quantity of the alternative fuel (if any) consumed by that vehicle (e.g., $\mathrm{kWh}$ used by electric vehicles). Within the USAGE module, the latter (known as substitution-fuel use) is computed as the sum of the product of VMT and advanced-technology GEMPG (the product of gasolineequivalent mpg and the Btu content of the fuel relative to gasoline) for each vintage.

First, VMT must be computed, as in Equation 5:

$$
\mathrm{M}_{\mathrm{j}}=M_{0} \times e^{(\text {UDRATE } \times j)},
$$

where:

$$
\begin{array}{ll}
M_{0} & =\text { annual miles per vehicle, age } 0 ; \\
M_{j} & =\text { annual miles per vehicle, age } j ; \text { and } \\
\text { UDRATE } & =\text { usage depreciation rate. }
\end{array}
$$

3 Note that age-dependent utilization can be adjusted to account for limited range. Thus, for example, EVs might travel only two-thirds as many miles per year as conventional vehicles.

4 For bi-fuel technologies in which petroleum is not totally displaced (e.g., dedicated ethanol vehicles running on an $85 \%$ ethanol fuel or flex-fuel vehicles), potential oil displacement is multiplied by the share of VMT run on alternative fuel for each vintage. Total displacement is then the sum of these products. 
Results from the vehicle stock model, which yields the number of vehicles of a given age, are then combined with the exogenous variable $V_{j}$ (the miles traveled for a given age) to determine VMT in any given year. The equation specification is given below:

$$
\mathrm{VMT}_{\mathrm{i}}=\sum_{j} V M T_{i j}=\sum_{j} V_{i j} \times M_{j},
$$

where:

$$
\begin{aligned}
& \mathrm{M}_{\mathrm{j}} \quad=\text { annual miles per vehicle, age } \mathrm{j} \text {, and } \\
& \mathrm{VMT}_{\mathrm{ij}} \quad=\text { total vehicle-miles traveled, year } \mathrm{i} \text { and age } \mathrm{j} .
\end{aligned}
$$

Potential gasoline displacement is calculated from miles traveled by the advancedtechnology vehicles and miles per gallon of the new conventional vehicles that are being displaced, as shown in Equation 7:

$$
\mathrm{PGD}_{i}=\sum_{j} \frac{V M T_{i j}}{N M P G_{k}},
$$

where:

$$
\begin{aligned}
& \mathrm{NMPG}_{\mathrm{k}}= \begin{array}{l}
\text { miles per gallon of the new conventional vehicle replaced by } \\
\text { the advanced-technology vehicle, model year } \mathrm{k} \text {, and }
\end{array} \\
& \mathrm{PGD}_{\mathrm{i}}=\text { potential gasoline displaced (gallons), year } \mathrm{i} .
\end{aligned}
$$

Several technology-specific parameters are used to compute fuel substitution (i.e., alternative-fuel consumption):

$$
\operatorname{AFUSE}_{i}=\sum_{j}\left(\frac{V M T_{i j} \times A F S H A R E_{i}}{G{ }^{\prime} M P G_{k} \times B R A T E \times E R A T E}\right),
$$

where:

$$
\begin{aligned}
& \text { GEMPG }_{\mathrm{k}} \quad \text { gasoline-equivalent mpg, model year } \mathrm{k} ; \\
& \text { BRATE } \\
& \text { ERATE }
\end{aligned}
$$


For flexibly fueled vehicles, five additional parameters are included in the fuelsubstitution module: (1) alcohol share of gasoline, (2) ethanol and (3) methanol shares of fuel-alcohol use, and (4) ethanol and (5) methanol-fuel use. In the current version of the model, the share of methanol is not estimated, and the share of ethanol is estimated from an exogenous forecast of biofuels production. The default production forecast (contained in the FLEX worksheet) was developed by the DOE/OTT (U.S. DOE 1994a). The default forecast assumes that real prices for biofuels decline and bioethanol accounts for $100 \%$ of biofuels production. ${ }^{5}$ Thus, ethanol shares are supply-constrained to the sum of current and new production capacity.

For electric and grid-connected hybrid vehicles, two additional parameters, transmission and distribution efficiencies, are used to account for losses between the power plant and vehicle. Fuel conversion efficiencies (e.g., to produce electricity or fuel-grade alcohol, or to compress natural gas) are not included in the fuel substitution calculation.

\subsubsection{EMISSIONS Module}

The EMISSIONS module estimates reductions in $\mathrm{NO}_{\mathrm{x}}, \mathrm{CO}$, and NMHC emissions associated with advanced-technology vehicles. Although $\mathrm{SO}_{\mathrm{x}}$ emissions are not estimated in the current version of the model, the worksheets have been designed so that users can add $\mathrm{SO}_{\mathrm{x}}$ emission rates and thus compute $\mathrm{SO}_{\mathrm{x}}$ emissions. All emission rates (in grams per mile) are modeled as a function of vehicle age or vintage. Emission reduction rates (in grams per mile by vintage) are obtained by subtracting the projected values from the conventionalvehicle values contained in the EMIS INPUTS worksheet. Within the EMISSIONS module, emissions reductions are computed as the sum of the product of VMT and the emissions reduction rate by vintage and are then converted to short tons. Because most of the technologies considered in IMPACTT are introduced after 2003, the conventional vehicles displaced by those technologies are assumed to meet Tier 2 emission standards, which are $50 \%$ of current Tier I standards. No conventional-technology improvements beyond Tier 2 standards are assumed. Thus, reductions in $\mathrm{g} / \mathrm{mi}$ emissions between conventional- and advanced-technology vehicles vary only with vehicle vintage, not future year.

As vehicles age, emissions from vehicles with heat engines are assumed to rise at the same rate as those from the conventional vehicles modeled in Mobile 5A. In other words, emission controls for advanced heat engines are assumed to degrade at the same rate as those for conventional internal-combustion engines because of a combination of aging equipment and inadequate operating conditions. Moveover, as the fleet of advancedtechnology vehicles ages and becomes as old as the fleet of conventional-technology vehicles that it is replacing, emissions reductions will become somewhat less for heat engines. For

5 An improved procedure for estimating fuel shares is currently under development. That procedure is expected to be based on algorithms developed for the Alternative Fuels Trade Model (AFTM) (Greene, Choice of Alternative Fuels and Alternative Fuel Vehicles in the AFTM, Oak Ridge National Laboratory, Aug. 1993). 
fuel-cell, electric, and hybrid vehicles operating in the electric mode, degradation is not expected to occur; therefore, emissions reductions increase as the advanced-technology fleet ages.

The emission reduction rates for $\mathrm{NO}_{\mathrm{x}}, \mathrm{CO}$, and exhaust $\mathrm{NMHC}$ (in grams per mile) for a given year are calculated as follows:

$$
E_{R R A T E} l=\left(T E M I S C_{j l}+R E M I S C_{j l}\right)-\left(T E M I S A_{j l}+R E M I S A_{j l}\right)
$$

where:

$$
\begin{aligned}
\text { TEMISC }_{\mathrm{jl}}= & \begin{array}{l}
\text { tailpipe emission rate; conventional-technology vehicle, age } \\
\mathrm{j} ; \text { pollutant } \mathrm{l} ;
\end{array} \\
\text { EMISA }_{j 1}= & \begin{array}{l}
\text { tailpipe emission rate; advanced-technology vehicle, age } \mathrm{j} ; \\
\text { pollutant } \mathrm{l} ;
\end{array} \\
\text { REMISC }_{1}= & \begin{array}{l}
\text { refinery (or power-plant) emission rate, conventional fuel, } \\
\text { pollutant } 1 ;
\end{array} \\
\text { REMISA }_{1}= & \begin{array}{l}
\text { refinery (or power-plant) emission rate, alternative fuel, } \\
\text { pollutant } l ; \text { and }
\end{array} \\
\text { ERRATE }_{\mathrm{jl}=}= & \begin{array}{l}
\text { emission reduction rate in } \mathrm{g} / \mathrm{mi} \text {, age } \mathrm{j}, \text { pollutant } 1 \text { for an } \\
\text { advanced-technology vehicle. }
\end{array}
\end{aligned}
$$

Emission reductions for each pollutant are calculated according to Equation 10. The factor 907,200 is used to convert grams into the reported unit of thousands of short tons.

$$
E M R E D_{i l}=\frac{\sum_{j} E R R A T E_{j l} \times V M T_{i j}}{(907,200)},
$$

where:

$$
\begin{aligned}
& \text { EMRED }_{\mathrm{il}}=\begin{array}{l}
\text { Emissions reduction for all advanced-technology vehicles in } \\
\text { short tons, year } \mathrm{i}, \text { pollutant } \mathrm{l} ;
\end{array} \\
& \mathrm{ERRATE}_{\mathrm{jl}}=\text { Emissions reduction rate in } \mathrm{g} / \mathrm{mi} \text {, age } \mathrm{j}, \text { pollutant } \mathrm{l} \text {; and } \\
& \mathrm{VMT}_{\mathrm{ij}}=\text { Vehicle-miles traveled, year } \mathrm{i} \text {, age } \mathrm{j} .
\end{aligned}
$$

Emissions reductions are reported in short tons per year, as well as by dollar value. A series of damage cost factors, developed by the Congressional Budget Office, is used to convert physical quantities into dollar values, which are summed across years and pollutants to produce a single environmental benefit associated with each advanced technology. Damage 
cost factors are based on the cost (in $1992 \$ /$ ton) of removing one ton of $\mathrm{NO}_{\mathrm{x}}, \mathrm{CO}$, and $\mathrm{NMHC}$ emissions from stationary sources. 


\section{INPUT DATA}

\subsection{VEHICLE STOCK CALCULATIONS}

IMPACTT operates on a set of assumptions that define a particular scenario. Chief among these assumptions are market-penetration rates for the various advanced technologies, which are a key component of the vehicle stock calculation. The default assumption in IMPACTT is that advanced-technology vehicles replace conventional vehicles on a one-for-one basis. The only exception is for advanced-battery electric vehicles, which are assumed to have a small, unique market demand (i.e., $10 \%$ of all electric vehicle sales). ${ }^{6}$ For the OTT program plan, market-penetration assumptions for the candidate OTT-supported technologies in the light-duty-vehicle (LDV) market were produced by the Alternative Vehicle Sales (AVS) vehicle-choice model (Fulton 1991). Any vehicle-choice model (or set of assumed penetration rates) could provide the required market-penetration inputs for IMPACTT. Tables 7 and 8 present default market-penetration assumptions for light- and heavy-duty-vehicle markets, respectively.

To estimate the number of new advanced-technology vehicles on the road in any given year, market-penetration rates must be combined with an external forecast of new vehicle sales by vehicle type, and vehicles must be tracked through a survival or vintaging procedure. The default forecast of vehicle sales contained in IMPACTT is provided in Table 2. The internal scrappage function uses two basic input parameters, $A_{0}$ and $A_{1}$, which are set at $A_{0}=0.7355$ and $A_{1}=6.0917$ in the current version of the model.

In IMPACTT, heavy-duty-vehicle stocks are calculated by applying survival rates reported in Davis and Strang (1993). Rates represent the probability of all classes of trucks of a given vintage surviving to a particular age. To reflect the assumed longer life expectancy of medium trucks, the survival function corresponding to data from 1966-1973 was used for that size class, while the function corresponding to 1978-1989 was used for heavy trucks.

\subsection{USAGE CALCULATIONS}

The USAGE module estimates VMT per year as a function of vehicle age. The key parameters - miles per year for a new vehicle and a degradation rate - are the same for most light-duty-vehicle technologies. The key exception is advanced-battery electric vehicles, the usage of which is assumed to be two-thirds that of conventional light-duty vehicles. The reduced miles-per-year assumption by vehicle age is embedded into the usage module calculation for electric vehicles. The standard, default numbers of miles per year by vehicle age are listed in Table 9.

6 This assumption is scenario-specific and can be modified by changing the market-penetration assumptions in the INPUTS worksheet and by inserting appropriate factors to adjust substitutionfuel use. 
TABLE 7 Default Market Penetration of Total Light-Duty Vehicles

\begin{tabular}{|c|c|c|c|c|c|c|c|}
\hline \multirow[b]{2}{*}{ Year } & \multicolumn{7}{|c|}{ Share of Sales of New Light-Duty Vehicles by Technology or Fuel } \\
\hline & Hybrid & $\begin{array}{l}\text { Electric } \\
\text { Vehicle }\end{array}$ & $\begin{array}{l}\text { Fuel } \\
\text { Cell }\end{array}$ & $\begin{array}{c}\text { Flex } \\
\text { ETOH }^{\mathrm{a}}\end{array}$ & $\begin{array}{c}\text { Ded. } \\
\text { ETOH }^{b}\end{array}$ & $\mathrm{CNG}^{\mathrm{c}}$ & $\mathrm{LPG}^{\circ}$ \\
\hline 1995 & 0 & 0 & 0 & 0.009 & 0 & 0.005 & 0.005 \\
\hline 1996 & 0 & 0 & 0 & 0.019 & 0 & 0.006 & 0.008 \\
\hline 1997 & 0 & 0.001 & 0 & 0.030 & 0 & 0.008 & 0.012 \\
\hline 1998 & 0 & 0.002 & 0 & 0.040 & 0 & 0.010 & 0.015 \\
\hline 1999 & 0 & 0.003 & 0 & 0.050 & 0 & 0.012 & 0.019 \\
\hline 2000 & 0 & 0.004 & 0 & 0.061 & 0 & 0.014 & 0.022 \\
\hline 2001 & 0 & 0.007 & 0 & 0.071 & 0 & 0.017 & 0.024 \\
\hline 2002 & 0 & 0.010 & 0 & 0.081 & 0 & 0.019 & 0.025 \\
\hline 2003 & 0.010 & 0.013 & 0 & 0.091 & 0.010 & 0.022 & 0.027 \\
\hline 2004 & 0.033 & 0.016 & 0 & 0.102 & 0.015 & 0.024 & 0.028 \\
\hline 2005 & 0.057 & 0.019 & 0 & 0.112 & 0.019 & 0.027 & 0.030 \\
\hline 2006 & 0.080 & 0.019 & 0 & 0.113 & 0.022 & 0.033 & 0.032 \\
\hline 2007 & 0.103 & 0.020 & 0.011 & 0.115 & 0.024 & 0.038 & 0.035 \\
\hline 2008 & 0.126 & 0.020 & 0.016 & 0.116 & 0.027 & 0.044 & 0.037 \\
\hline 2009 & 0.150 & 0.020 & 0.021 & 0.118 & 0.029 & 0.049 & 0.040 \\
\hline 2010 & 0.173 & 0.021 & 0.026 & 0.119 & 0.032 & 0.055 & 0.042 \\
\hline 2011 & 0.181 & 0.021 & 0.030 & 0.124 & 0.036 & 0.057 & 0.044 \\
\hline 2012 & 0.188 & 0.021 & 0.035 & 0.129 & 0.040 & 0.059 & 0.045 \\
\hline 2013 & 0.196 & 0.021 & 0.039 & 0.134 & 0.044 & 0.061 & 0.047 \\
\hline 2014 & 0.203 & 0.021 & 0.044 & 0.139 & 0.048 & 0.063 & 0.048 \\
\hline 2015 & 0.211 & 0.022 & 0.048 & 0.145 & 0.052 & 0.065 & 0.050 \\
\hline 2016 & 0.219 & 0.024 & 0.059 & 0.150 & 0.055 & 0.066 & 0.052 \\
\hline 2017 & 0.226 & 0.026 & 0.070 & 0.155 & 0.059 & 0.068 & 0.053 \\
\hline 2018 & 0.234 & 0.028 & 0.081 & 0.160 & 0.063 & 0.070 & 0.055 \\
\hline 2019 & 0.241 & 0.030 & 0.092 & 0.165 & 0.067 & 0.072 & 0.056 \\
\hline 2020 & 0.249 & 0.032 & 0.103 & 0.170 & 0.071 & 0.074 & 0.058 \\
\hline 2021 & 0.248 & 0.032 & 0.106 & 0.169 & 0.074 & 0.073 & 0.058 \\
\hline 2022 & 0.247 & 0.032 & 0.110 & 0.168 & 0.076 & 0.072 & 0.057 \\
\hline 2023 & 0.245 & 0.032 & 0.113 & 0.168 & 0.079 & 0.071 & 0.057 \\
\hline 2024 & 0.244 & 0.032 & 0.117 & 0.167 & 0.081 & 0.070 & 0.056 \\
\hline 2025 & 0.243 & 0.032 & 0.120 & 0.166 & 0.084 & 0.069 & 0.056 \\
\hline 2026 & 0.242 & 0.033 & 0.123 & 0.165 & 0.087 & 0.068 & 0.055 \\
\hline 2027 & 0.240 & 0.033 & 0.127 & 0.165 & 0.090 & 0.067 & 0.055 \\
\hline 2028 & 0.239 & 0.033 & 0.130 & 0.164 & 0.092 & 0.065 & 0.054 \\
\hline 2029 & 0.237 & 0.033 & 0.134 & 0.164 & 0.095 & 0.064 & 0.054 \\
\hline 2030 & 0.236 & 0.033 & 0.137 & 0.163 & 0.098 & 0.063 & 0.053 \\
\hline
\end{tabular}

a Flex ETOH = Flexible-fuel ethanol.

b Ded. ETOH = Dedicated ethanol.

c $\mathrm{CNG}=$ Compressed natural gas.

d LPG = Liquid petroleum gas (propane).

Source: AVS model, Feb. 8, 1994, run. 
TABLE 8 Default Market Penetration of Medium and Heavy Trucks

\begin{tabular}{|c|c|c|c|c|c|}
\hline \multirow[b]{3}{*}{ Year } & \multicolumn{5}{|c|}{$\begin{array}{c}\text { Share of Sales of New Heavy-Duty Vehicles by } \\
\text { Technology or Fuel }\end{array}$} \\
\hline & \multicolumn{3}{|c|}{ Medium Trucks } & \multicolumn{2}{|c|}{ Heavy Trucks } \\
\hline & Fuel Cell & $\mathrm{CNG}^{\mathrm{a}}$ & $\mathrm{LPG}^{\mathrm{b}}$ & Fuel Cell & LE55 \\
\hline 1995 & - & 0.01 & 0 & - & - \\
\hline 1996 & - & 0.02 & 0.01 & - & 0 \\
\hline 1997 & - & 0.05 & 0.02 & - & 0 \\
\hline 1998 & - & 0.07 & 0.03 & - & 0 \\
\hline 1999 & - & 0.08 & 0.05 & - & 0 \\
\hline 2000 & - & 0.10 & 0.05 & - & 0 \\
\hline 2001 & - & 0.13 & 0.08 & - & 0.01 \\
\hline 2002 & - & 0.16 & 0.08 & - & 0.04 \\
\hline 2003 & - & 0.19 & 0.10 & - & 0.08 \\
\hline 2004 & - & 0.22 & 0.11 & - & 0.12 \\
\hline 2005 & - & 0.24 & 0.12 & - & 0.16 \\
\hline 2006 & - & 0.25 & 0.13 & - & 0.20 \\
\hline 2007 & - & 0.27 & 0.14 & - & 0.24 \\
\hline 2008 & - & 0.29 & 0.15 & - & 0.28 \\
\hline 2009 & 0 & 0.31 & 0.16 & - & 0.32 \\
\hline 2010 & 0.01 & 0.33 & 0.17 & 0 & 0.36 \\
\hline 2011 & 0.03 & 0.34 & 0.17 & 0.01 & 0.40 \\
\hline 2012 & 0.07 & 0.35 & 0.18 & 0.03 & 0.42 \\
\hline 2013 & 0.11 & 0.35 & 0.18 & 0.07 & 0.44 \\
\hline 2014 & 0.16 & 0.36 & 0.18 & 0.11 & 0.46 \\
\hline 2015 & 0.21 & 0.37 & 0.19 & 0.16 & 0.48 \\
\hline 2016 & 0.27 & 0.38 & 0.19 & 0.21 & 0.50 \\
\hline 2017 & 0.32 & 0.38 & 0.19 & 0.27 & 0.53 \\
\hline 2018 & 0.36 & 0.39 & 0.20 & 0.32 & 0.55 \\
\hline 2019 & 0.38 & 0.40 & 0.20 & 0.36 & 0.58 \\
\hline 2020 & 0.40 & 0.40 & 0.20 & 0.38 & 0.59 \\
\hline 2021 & 0.40 & 0.40 & 0.20 & 0.40 & 0.60 \\
\hline 2022 & 0.40 & 0.40 & 0.20 & 0.40 & 0.60 \\
\hline 2023 & 0.40 & 0.40 & 0.20 & 0.40 & 0.60 \\
\hline 2024 & 0.40 & 0.40 & 0.20 & 0.40 & 0.60 \\
\hline 2025 & 0.40 & 0.40 & 0.20 & 0.40 & 0.60 \\
\hline 2026 & 0.40 & 0.40 & 0.20 & 0.40 & 0.60 \\
\hline 2027 & 0.40 & 0.40 & 0.20 & 0.40 & 0.60 \\
\hline 2028 & 0.40 & 0.40 & 0.20 & 0.40 & 0.60 \\
\hline 2029 & 0.40 & 0.40 & 0.20 & 0.40 & 0.60 \\
\hline 2030 & 0.40 & 0.40 & 0.20 & 0.40 & 0.60 \\
\hline
\end{tabular}

a $\mathrm{CNG}=$ Compressed natural gas.

b $L P G=$ Liquid petroleum gas (propane).

c LE55 = Low-emission, 55\% thermal-efficiency diesel engines.

Source: OTT 1994. 


\subsection{ENERGY CALCULATIONS}

Energy consumption/savings estimates are based on a number of technology-specific assumptions. The calculation of oil displacement is a function of miles traveled and the efficiency (mpg) of new conventional vehicles (see Table 3). For light-duty vehicles, the EPA test mpg was adjusted by a factor of 0.8 to reflect a typical shortfall or gap between test conditions and actual on-road experience. The Btu and efficiency rates are used to estimate substitution effects (i.e., consumption of alternative fuels in lieu of conventional fuels). The Btu rate is the ratio of the lower heating value for the alternative fuel to the lower heating value for the conventional fuel.

Fuel efficiency is represented by two variables, GEMPG and ERATE. When the user wishes to specify a general improvement, ERATE should be set to the desired value. When specific improvements are known or the rate of improvement is assumed to vary over time, values of advanced-technology fuel efficiency (GEMPG) should be entered directly by year, and the default value of ERATE should be set at 1.0. Alternatively, the user can specify an efficiency rate (ERATE) different from 1.0 (as well as GEMPG values by year) to simulate a scenario in which both general improvements occur and the engine is optimized to take full advantage of an alternative fuel's properties. The default value for ERATE is 1.0; default values for GEMPG are those assumed for DOE/OTT 1994 and are shown in Table 10.

\subsection{EMISSIONS CALCULATIONS}

The EMISSIONS module first determines the difference in emission rates between a conventional vehicle and an advanced-technology vehicle. For light-duty vehicles, input parameters are Tier 2 emissions standards (degraded to estimated on-road performance by vehicle age by using MOBILE5a degradation factors for autos and light-duty trucks), estimated emissions from advanced-technology vehicles (also by age), and refinery and powerplant emission rates. In the default case, advanced technologies are assumed to degrade at the same rate as conventional vehicles, dedicated-alcohol and flexible-fueled vehicles are assumed to have essentially the same tailpipe emissions as gasoline-fueled vehicles, and CNG vehicles are assumed to achieve a $7 \%$ reduction in $\mathrm{CO}$ emissions relative to gasoline vehicles. Hybrids are assumed to achieve Tier 2 emissions standards when operating on a heat engine. Advanced-battery electric vehicles, hybrids operating on grid-supplied electricity, and fuelcell-powered vehicles are assumed to be zero-emission vehicles $(0.2 \mathrm{~g} / \mathrm{mi} \mathrm{NO}, 0.04 \mathrm{~g} / \mathrm{mi} \mathrm{CO}$, $0.01 \mathrm{~g} / \mathrm{mi} \mathrm{NMHCs}$, and $0.46 \mathrm{~g} / \mathrm{mi} \mathrm{SO}_{\mathrm{x}}$ for electric vehicles and $0.001 \mathrm{~g} / \mathrm{mi} \mathrm{NO}$, essentially zero $\mathrm{CO}, 0.002 \mathrm{~g} / \mathrm{mi}$ NMHCs, and essentially zero $\mathrm{SO}_{\mathrm{x}}$ for fuel-cell vehicles).

Both tailpipe and refinery (or power-plant) values are included in the default calculation. Users can exclude refinery (or power-plant) values by eliminating those terms from the formula. 
TABLE 10 Default Gasoline-Equivalent Miles per Gallon of New Advanced-Technology, Light-Duty Vehicles

\begin{tabular}{|c|c|c|c|c|c|c|c|}
\hline \multirow[b]{2}{*}{ Year } & \multicolumn{7}{|c|}{ Fuel or Technology ${ }^{a}$} \\
\hline & CNG & LPG & $\begin{array}{c}\text { Flex } \\
\text { ETOH }\end{array}$ & Hybrid & EV & Fuel Cell & Ded. ETOH \\
\hline 1990 & 20.3 & 20.3 & 20.3 & - & - & - & 20.3 \\
\hline 1991 & 20.3 & 20.3 & 20.3 & - & - & - & 20.3 \\
\hline 1992 & 20.1 & 20.1 & 20.1 & - & - & - & 20.1 \\
\hline 1993 & 20.2 & 20.2 & 20.2 & - & - & - & 20.2 \\
\hline 1994 & 20.3 & 20.3 & 20.3 & - & - & - & 20.3 \\
\hline 1995 & 20.4 & 20.4 & 20.4 & - & - & - & 20.4 \\
\hline 1996 & 20.6 & 20.6 & 20.6 & - & - & - & 20.6 \\
\hline 1997 & 20.8 & 20.8 & 20.8 & _- & 48.9 & - & 20.8 \\
\hline 1998 & 20.9 & 20.9 & 20.9 & - & 52.7 & - & 20.9 \\
\hline 1999 & 21.0 & 21.0 & 21.0 & - & 56.6 & - & 21.0 \\
\hline 2000 & 21.1 & 21.1 & 21.1 & - & 60.6 & - & 21.1 \\
\hline 2001 & 21.3 & 21.3 & 21.3 & - & 64.6 & - & 21.3 \\
\hline 2002 & 21.4 & 21.4 & 21.4 & - & 68.7 & - & 21.4 \\
\hline 2003 & 21.6 & 21.6 & 21.6 & 30.6 & 72.8 & - & 21.6 \\
\hline 2004 & 21.7 & 21.7 & 21.7 & 35.2 & 77.1 & - & 21.7 \\
\hline 2005 & 21.9 & 21.9 & 21.9 & 39.6 & 81.4 & - & 21.9 \\
\hline 2006 & 22.0 & 22.0 & 22.0 & 44.3 & 82.0 & - & 22.0 \\
\hline 2007 & 22.2 & 22.2 & 22.2 & 48.8 & 82.5 & 42.6 & 22.2 \\
\hline 2008 & 22.3 & 22.3 & 22.3 & 53.5 & 83.0 & 45.6 & 22.3 \\
\hline 2009 & 22.4 & 22.4 & 22.4 & 53.8 & 83.4 & 48.7 & 22.4 \\
\hline 2010 & 22.5 & 22.5 & 22.5 & 54.0 & 83.8 & 51.7 & 22.5 \\
\hline 2011 & 22.5 & 22.5 & 22.5 & 54.0 & 83.8 & 54.6 & 22.5 \\
\hline 2012 & 22.5 & 22.5 & 22.5 & 54.0 & 83.7 & 57.4 & 22.5 \\
\hline 2013 & 22.5 & 22.5 & 22.5 & 54.0 & 83.7 & 60.2 & 22.5 \\
\hline 2014 & 22.5 & 22.5 & 22.5 & 54.0 & 83.7 & 63.0 & 22.5 \\
\hline 2015 & 22.5 & 22.5 & 22.5 & 54.0 & 83.7 & 65.9 & 22.5 \\
\hline 2016 & 22.5 & 22.5 & 22.5 & 54.0 & 83.7 & 68.7 & 22.5 \\
\hline 2017 & 22.5 & 22.5 & 22.5 & 54.0 & 83.6 & 71.5 & 22.5 \\
\hline 2018 & 22.5 & 22.5 & 22.5 & 54.0 & 83.6 & 71.5 & 22.5 \\
\hline 2019 & 22.5 & 22.5 & 22.5 & 53.9 & 83.6 & 71.5 & 22.5 \\
\hline 2020 & 22.5 & 22.5 & 22.5 & 53.9 & 83.6 & 71.5 & 22.5 \\
\hline 2021 & 22.5 & 22.5 & 22.5 & 53.9 & 83.6 & 71.5 & 22.5 \\
\hline 2022 & 22.5 & 22.5 & 22.5 & 53.9 & 83.6 & 71.4 & 22.5 \\
\hline 2023 & 22.5 & 22.5 & 22.5 & 53.9 & 83.6 & 71.4 & 22.5 \\
\hline 2024 & 22.5 & 22.5 & 22.5 & 53.9 & 83.6 & 71.4 & 22.5 \\
\hline 2025 & 22.5 & 22.5 & 22.5 & 53.9 & 83.5 & 71.4 & 22.5 \\
\hline 2026 & 22.5 & 22.5 & 22.5 & 53.9 & 83.5 & 71.4 & 22.5 \\
\hline 2027 & 22.4 & 22.4 & 22.4 & 53.9 & 83.5 & 71.4 & 22.4 \\
\hline 2028 & 22.4 & 22.4 & 22.4 & 53.9 & 83.5 & $71 . \dot{4}$ & 22.4 \\
\hline 2029 & 22.4 & 22.4 & 22.4 & 53.9 & 83.5 & 71.4 & 22.4 \\
\hline 2030 & 22.4 & 22.4 & 22.4 & 53.9 & 83.5 & 71.4 & 22.4 \\
\hline
\end{tabular}

a $\mathrm{CNG}=$ compressed natural gas, $\mathrm{LPG}=$ liquid petroleum gas (propane), Flex ETOH = flexible-fuel ethanol, EV = electric vehicle, and Ded. ETOH $=$ dedicated ethanol. 


\section{SAMPLE OUTPUT}

Tables 2-10 contain the key inputs needed to define a full eight-technology (seven advanced and one conventional) IMPACTT scenario. Rather than reproducing the full workbook for that run (hardcopies of all 16 worksheets would occupy 62 pages), only portions of the five output worksheets are shown in Tables 11-17. Table 11 is from the VMT SUM worksheet, Tables 12 and 13 are from CON SUM, Tables 14 and 15 are from RED SUM and EMIS SUM, and Tables 16 and 17 are from OIL SUM. 
TABLE 11 Vehicle Miles Traveled by Advanced-Technology, Light-Duty Vehicles

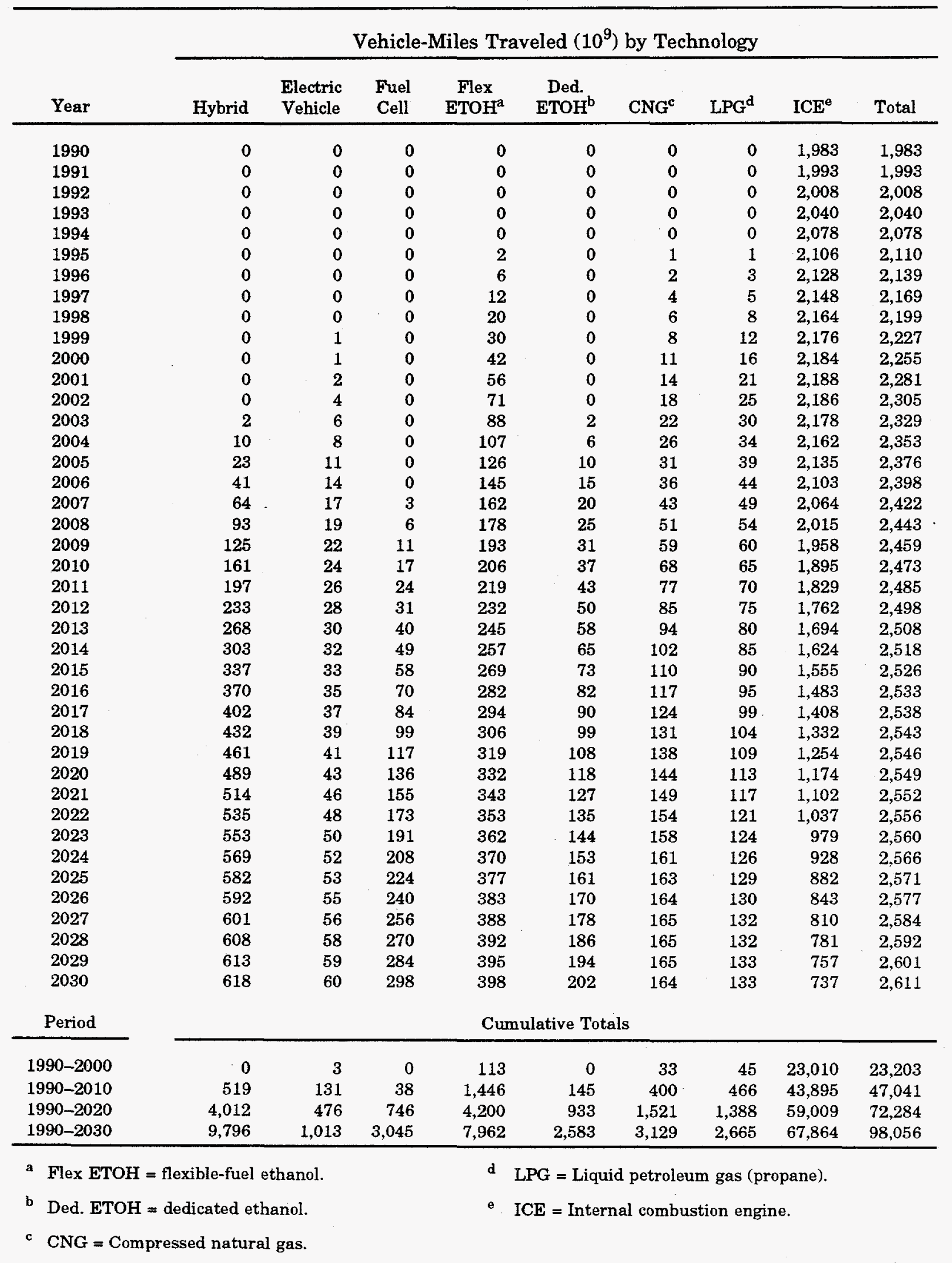


TABLE 12 Fuel Consumption of Light-Duty Vehicles by Fuel Type

\begin{tabular}{|c|c|c|c|c|c|c|c|}
\hline \multirow[b]{2}{*}{ Year } & \multicolumn{7}{|c|}{ Fuel Consumption $\left(10^{9} \mathrm{bbl} /\right.$ day $)$ by Fuel Type } \\
\hline & $\mathrm{ETOH}^{\mathrm{a}}$ & $\mathrm{MEOH}^{\mathbf{b}}$ & $\mathrm{CNG}^{\mathrm{c}}$ & $\mathrm{LPG}^{\mathrm{d}}$ & Electricity & Gasoline & Total \\
\hline 1990 & 0 & 0 & 0 & 0 & 0 & 6.11 & 6.11 \\
\hline 1991 & 0 & 0 & 0 & 0 & 0 & 6.07 & 6.07 \\
\hline 1992 & 0 & 0 & 0 & 0 & 0 & 6.07 & 6.07 \\
\hline 1993 & 0 & 0 & 0 & 0 & 0 & 6.12 & 6.12 \\
\hline 1994 & 0 & 0 & 0 & 0 & 0 & 6.20 & 6.20 \\
\hline 1995 & 0 & 0 & 0 & 0 & 0 & 6.25 & 6.25 \\
\hline 1996 & 0 & 0 & 0 & 0.01 & 0 & 6.29 & 6.31 \\
\hline 1997 & 0 & 0 & 0.01 & 0.01 & 0 & 6.34 & 6.36 \\
\hline 1998 & 0 & 0 & 0.02 & 0.02 & 0 & 6.38 & 6.42 \\
\hline 1999 & 0 & 0 & 0.02 & 0.03 & 0 & 6.41 & 6.47 \\
\hline 2000 & 0 & 0 & 0.03 & 0.05 & 0 & 6.43 & 6.50 \\
\hline 2001 & 0 & 0 & 0.04 & 0.06 & 0 & 6.44 & 6.54 \\
\hline 2002 & 0 & 0 & 0.05 & 0.07 & 0 & 6.45 & 6.57 \\
\hline 2003 & 0.01 & 0 & 0.06 & 0.08 & 0.01 & 6.44 & 6.60 \\
\hline 2004 & 0.02 & 0 & 0.07 & 0.10 & 0.02 & 6.41 & 6.61 \\
\hline 2005 & 0.05 & 0 & 0.08 & 0.11 & 0.03 & 6.35 & 6.61 \\
\hline 2006 & 0.07 & 0 & 0.09 & 0.12 & 0.04 & 6.27 & 6.60 \\
\hline 2007 & 0.11 & 0 & 0.11 & 0.14 & 0.06 & 6.16 & 6.58 \\
\hline 2008 & 0.17 & 0.01 & 0.13 & 0.15 & 0.08 & 6.01 & 6.54 \\
\hline 2009 & 0.29 & 0.02 & 0.15 & 0.16 & 0.10 & 5.78 & 6.49 \\
\hline 2010 & 0.53 & 0.02 & 0.17 & 0.18 & 0.12 & 5.40 & 6.42 \\
\hline 2011 & 0.62 & 0.03 & 0.19 & 0.19 & 0.14 & 5.18 & 6.35 \\
\hline 2012 & 0.70 & 0.04 & 0.21 & 0.20 & 0.17 & 4.96 & 6.28 \\
\hline 2013 & 0.79 & 0.05 & 0.23 & 0.22 & 0.19 & 4.74 & 6.21 \\
\hline 2014 & 0.89 & 0.06 & 0.25 & 0.23 & 0.21 & 4.51 & 6.14 \\
\hline 2015 & 0.99 & 0.06 & 0.27 & 0.24 & 0.23 & 4.28 & 6.06 \\
\hline 2016 & 1.08 & 0.07 & 0.28 & 0.25 & 0.25 & 4.05 & 5.99 \\
\hline 2017 & 1.16 & 0.08 & 0.30 & 0.26 & 0.27 & 3.83 & 5.91 \\
\hline 2018 & 1.22 & 0.10 & 0.32 & 0.28 & 0.29 & 3.62 & 5.83 \\
\hline 2019 & 1.29 & 0.11 & 0.33 & 0.29 & 0.31 & 3.41 & 5.74 \\
\hline 2020 & 1.36 & 0.13 & 0.34 & 0.30 & 0.32 & 3.20 & 5.66 \\
\hline 2021 & 1.41 & 0.14 & 0.36 & 0.31 & 0.34 & 3.02 & 5.58 \\
\hline 2022 & 1.47 & 0.16 & 0.37 & 0.32 & 0.35 & 2.85 & 5.52 \\
\hline 2023 & 1.52 & 0.17 & 0.38 & 0.33 & 0.37 & 2.69 & 5.46 \\
\hline 2024 & 1.57 & 0.19 & 0.39 & 0.34 & 0.38 & 2.56 & 5.41 \\
\hline 2025 & 1.62 & 0.20 & 0.39 & 0.34 & 0.38 & 2.43 & 5.37 \\
\hline 2026 & 1.66 & 0.21 & 0.40 & 0.35 & 0.39 & 2.33 & 5.34 \\
\hline 2027 & 1.70 & 0.23 & 0.40 & 0.35 & 0.40 & 2.24 & 5.31 \\
\hline 2028 & 1.73 & 0.24 & 0.40 & 0.35 & 0.40 & 2.17 & 5.29 \\
\hline 2029 & 1.76 & 0.25 & 0.40 & 0.35 & 0.41 & 2.10 & 5.27 \\
\hline 2030 & 1.79 & 0.26 & 0.40 & 0.35 & 0.41 & 2.05 & 5.27 \\
\hline Period & \multicolumn{7}{|c|}{ Cumulative Totals } \\
\hline $1990-2000$ & 0 & 0 & 0.09 & 0.13 & 0 & 68.67 & 68.88 \\
\hline $1990-2010$ & 1.24 & 0.05 & 1.01 & 1.29 & 0.47 & 130.40 & 134.40 \\
\hline $1990-2020$ & 11.33 & 0.77 & 3.74 & 3.75 & 2.85 & 172.20 & 194.60 \\
\hline $1990-2030$ & 27.55 & 2.81 & 7.64 & 7.14 & 6.68 & 196.60 & 248.40 \\
\hline a ETOH = & & & & $\mathrm{CN}$ & ompress & 1atural $\xi$ & \\
\hline b $\mathrm{MEOH}=$ & & & & LPG & quid pe & am gas & pane). \\
\hline
\end{tabular}


TABLE 13 Stocks of Light-Duty Vehicles and Share of Alternative-Fuel Vehicles

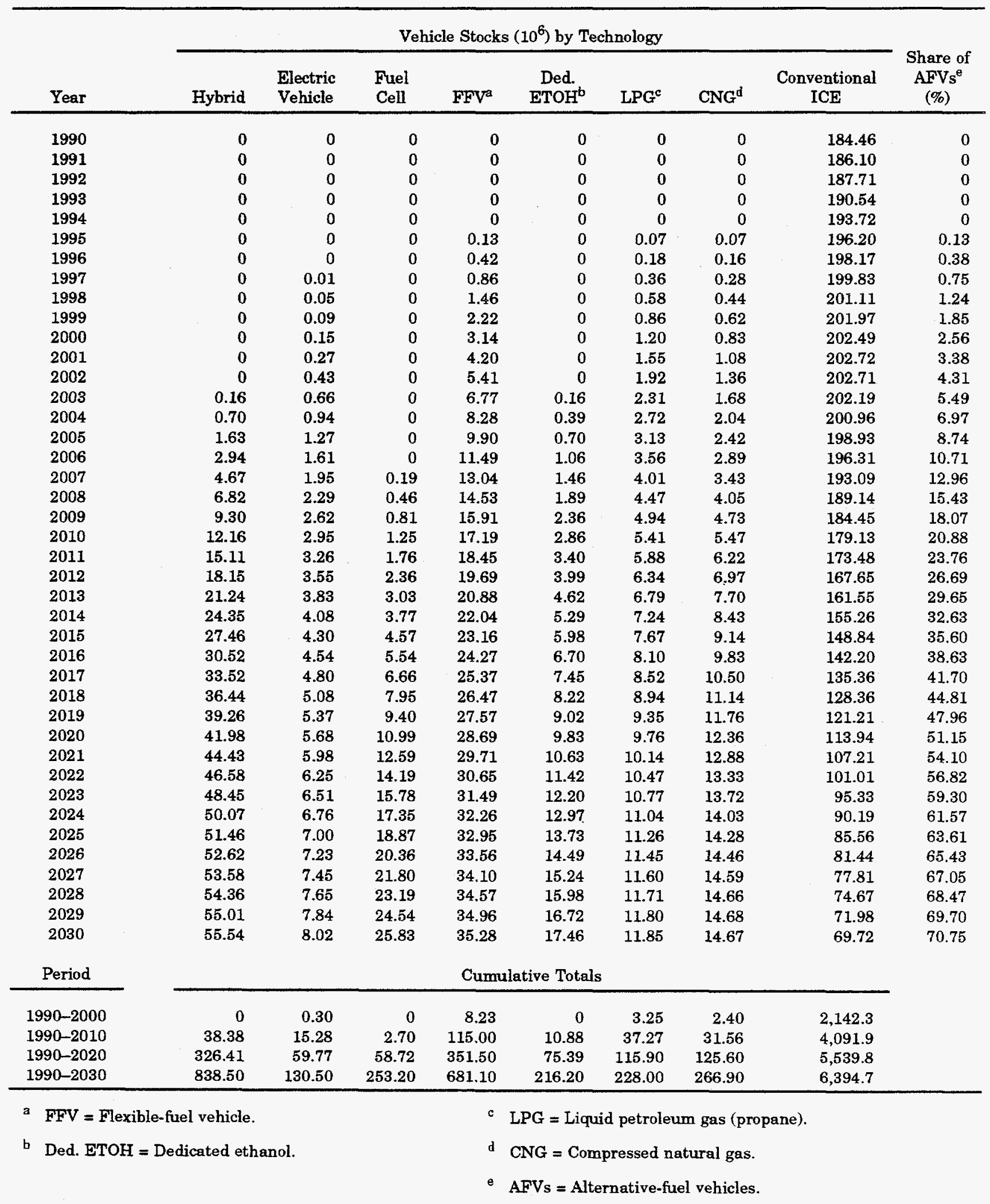


TABLE 14 Total Emissions Reduction from Seven Advanced Technologies

\begin{tabular}{|c|c|c|c|c|c|c|c|c|c|}
\hline \multirow[b]{3}{*}{ Year } & \multicolumn{5}{|c|}{ Total Emissions Reduction ( $10^{6}$ tons) } & \multirow{2}{*}{\multicolumn{4}{|c|}{$\begin{array}{c}\text { Monetary Value }\left(\$ 10^{9},\right. \\
1992 \text { dollars })^{\mathrm{a}}\end{array}$}} \\
\hline & \multirow[b]{2}{*}{$\mathrm{NO}_{x}$} & \multirow[b]{2}{*}{ Co } & \multirow[b]{2}{*}{$\mathrm{NMHC}$} & \multicolumn{2}{|c|}{$\mathrm{CO}_{2}$} & & & & \\
\hline & & & & Tailpipe & Upstream & $\mathrm{NO}_{\mathbf{x}}$ & $\mathrm{CO}$ & NMHC & Total \\
\hline & & & & & & 0 & 0 & 0 & 0 \\
\hline 1991 & 0 & 0 & 0 & 0 & 0 & 0 & 0 & 0 & 0 \\
\hline 1992 & 0 & 0 & 0 & 0 & 0 & 0 & 0 & 0 & 0 \\
\hline 1993 & 0 & 0 & 0 & 0 & 0 & 0 & 0 & 0 & 0 \\
\hline 1994 & 0 & 0 & 0 & 0 & 0 & 0 & 0 & 0 & 0 \\
\hline 1995 & 0 & 0 & 0 & 0.77 & 0.38 & 0 & 0 & 0 & 0 \\
\hline 1996 & 0 & 0 & 0 & 1.97 & 0.97 & 0 & 0 & 0 & 0 \\
\hline 1997 & 0 & 0 & 0 & 3.65 & 1.80 & 0 & 0 & 0 & 0 \\
\hline 1998 & 0 & 0.01 & 0 & 5.80 & 2.85 & 0 & 0 & 0 & 0.01 \\
\hline 1999 & 0 & 0.01 & 0 & 8.36 & 4.12 & 0 & 0 & 0 & 0.01 \\
\hline 2000 & 0 & 0.02 & 0 & 11.31 & 5.57 & 0 & 0.01 & 0 & 0.01 \\
\hline 2001 & 0 & 0.03 & 0 & 14.64 & 7.21 & 0.01 & 0.01 & 0.01 & 0.02 \\
\hline 2002 & 0 & 0.05 & 0 & 18.33 & 9.02 & 0.01 & 0.01 & 0.01 & 0.03 \\
\hline 2003 & 0 & 0.07 & 0 & 24.01 & 11.82 & 0.01 & 0.02 & 0.01 & 0.04 \\
\hline 2004 & 0.01 & 0.11 & 0.01 & 32.36 & 15.93 & 0.02 & 0.03 & 0.02 & 0.07 \\
\hline 2005 & 0.01 & 0.17 & 0.01 & 43.59 & 21.46 & 0.02 & 0.05 & 0.03 & 0.11 \\
\hline 2006 & 0.01 & 0.25 & 0.02 & 57.05 & 28.09 & 0.03 & 0.07 & 0.05 & 0.16 \\
\hline 2007 & 0.02 & 0.36 & 0.02 & 75.12 & 36.98 & 0.05 & 0.11 & 0.07 & 0.23 \\
\hline 2008 & 0.03 & 0.51 & 0.03 & 98.74 & 48.61 & 0.07 & 0.15 & 0.10 & 0.33 \\
\hline 2009 & 0.04 & 0.69 & 0.05 & 131.50 & 64.74 & 0.11 & 0.21 & 0.15 & 0.46 \\
\hline 2010 & 0.06 & 0.93 & 0.07 & 183.79 & 90.48 & 0.15 & 0.28 & 0.20 & 0.63 \\
\hline 2011 & 0.07 & 1.19 & 0.09 & 213.68 & 105.20 & 0.19 & 0.36 & 0.26 & 0.81 \\
\hline 2012 & 0.09 & 1.49 & 0.11 & 244.33 & 120.29 & 0.24 & 0.45 & 0.33 & 1.01 \\
\hline 2013 & 0.10 & 1.84 & 0.13 & 275.77 & 135.77 & 0.29 & 0.55 & 0.40 & 1.24 \\
\hline 2014 & 0.12 & 2.21 & 0.16 & 307.12 & 151.20 & 0.34 & 0.66 & 0.48 & 1.48 \\
\hline 2015 & 0.14 & 2.60 & 0.19 & 338.80 & 166.79 & 0.40 & 0.78 & 0.57 & 1.75 \\
\hline 2016 & 0.17 & 3.03 & 0.22 & 370.12 & 182.21 & 0.46 & 0.91 & 0.66 & 2.03 \\
\hline 2017 & 0.19 & 3.47 & 0.25 & 400.38 & 197.11 & 0.53 & 1.04 & 0.76 & 2.33 \\
\hline 2018 & 0.22 & 3.92 & 0.28 & 428.97 & 211.19 & 0.59 & 1.17 & 0.86 & 2.63 \\
\hline 2019 & 0.24 & 4.38 & 0.32 & 457.94 & 225.44 & 0.66 & 1.31 & 0.96 & 2.94 \\
\hline 2020 & 0.27 & 4.84 & 0.35 & 487.26 & 239.88 & 0.73 & 1.45 & 1.07 & 3.25 \\
\hline 2021 & 0.29 & 5.29 & 0.38 & 512.80 & 252.46 & 0.80 & 1.59 & 1.17 & 3.56 \\
\hline 2022 & 0.32 & 5.74 & 0.42 & 536.88 & 264.31 & 0.87 & 1.72 & 1.27 & 3.86 \\
\hline 2023 & 0.34 & 6.17 & 0.45 & 559.21 & 275.30 & 0.94 & 1.85 & 1.37 & $4.16^{\circ}$ \\
\hline 2024 & 0.36 & 6.60 & 0.48 & 579.74 & 285.41 & 1.00 & 1.98 & 1.46 & 4.44 \\
\hline 2025 & 0.39 & 7.02 & 0.51 & 598.54 & 294.67 & 1.06 & 2.10 & 1.56 & 4.72 \\
\hline 2026 & 0.41 & 7.41 & 0.54 & 614.67 & 302.61 & 1.12 & 2.22 & 1.65 & 4.99 \\
\hline 2027 & 0.43 & 7.79 & 0.57 & 629.13 & 309.73 & 1.17 & 2.34 & 1.73 & 5.25 \\
\hline 2028 & 0.45 & 8.14 & 0.60 & 642.04 & 316.08 & 1.23 & 2.44 & 1.82 & 5.49 \\
\hline 2029 & 0.47 & 8.47 & 0.62 & 653.63 & 321.79 & 1.28 & 2.54 & 1.89 & 5.71 \\
\hline 2030 & 0.48 & 8.76 & 0.64 & 664.05 & 326.92 & 1.33 & 2.63 & 1.96 & 5.92 \\
\hline Period & & & & & mulative $\mathrm{Tc}$ & & & & \\
\hline $1990-2000$ & 0 & 0.05 & 0 & 31.87 & 15.69 & 0.01 & 0.02 & 0.01 & 0.04 \\
\hline $1990-2010$ & 0.18 & 3.21 & 0.22 & 710.99 & 350.02 & 0.49 & 0.96 & 0.66 & 2.11 \\
\hline $1990-2020$ & 1.79 & 32.17 & 2.30 & $4,235.36$ & $2,085.10$ & 4.91 & 9.65 & 7.01 & 21.58 \\
\hline $1990-2030$ & 5.71 & 103.56 & 7.51 & $10,226.07$ & $5,034.37$ & 15.71 & 31.07 & 22.89 & 69.68 \\
\hline
\end{tabular}

a $\mathrm{NO}_{\mathrm{x}}, \mathrm{CO}$, and $\mathrm{NMHC}$ only. 
TABLE 15 Total Light-Duty Vehicle Emissions from All Advanced and Conventional Technologies

\begin{tabular}{|c|c|c|c|c|c|}
\hline \multirow[b]{3}{*}{ Year } & \multicolumn{5}{|c|}{ Emissions ( $10^{6}$ tons) by Type } \\
\hline & \multirow[b]{2}{*}{$\mathrm{NO}_{\mathrm{x}}$} & \multirow[b]{2}{*}{$\mathrm{CO}$} & \multirow[b]{2}{*}{ NMHC } & \multicolumn{2}{|c|}{$\mathrm{CO}_{2}$} \\
\hline & & & & Tailpipe & Upstream \\
\hline 1990 & 1.21 & 21.30 & 2.24 & 855.65 & 421.24 \\
\hline 1991 & 1.22 & 21.67 & 2.28 & 850.51 & 418.71 \\
\hline 1992 & 1.24 & 22.20 & 2.33 & 849.52 & 418.22 \\
\hline 1993 & 1.26 & 22.81 & 2.39 & 857.49 & 422.15 \\
\hline 1994 & 1.30 & 23.30 & 2.45 & 868.32 & 427.48 \\
\hline 1995 & 1.32 & 23.74 & 2.49 & 875.46 & 431.00 \\
\hline 1996 & 1.34 & 23.98 & 2.52 & 881.92 & 434.18 \\
\hline 1997 & 1.36 & 24.30 & 2.55 & 888.81 & 437.57 \\
\hline 1998 & 1.38 & 24.55 & 2.58 & 895.34 & 440.78 \\
\hline 1999 & 1.39 & 24.83 & 2.61 & 901.37 & 443.75 \\
\hline 2000 & 1.40 & 25.02 & 2.64 & 904.12 & 445.10 \\
\hline 2001 & 1.42 & 25.28 & 2.66 & 907.52 & 446.78 \\
\hline 2002 & 1.43 & 25.55 & 2.68 & 909.76 & 447.88 \\
\hline 2003 & 1.44 & 25.79 & 2.69 & 910.41 & 448.20 \\
\hline 2004 & 1.45 & 25.99 & 2.70 & 907.96 & 447.00 \\
\hline 2005 & 1.46 & 26.23 & 2.72 & 901.40 & 443.77 \\
\hline 2006 & 1.48 & 26.46 & 2.73 & 892.28 & 439.27 \\
\hline 2007 & 1.49 & 26.68 & 2.74 & 879.66 & 433.06 \\
\hline 2008 & 1.50 & 26.87 & 2.75 & 860.70 & 423.73 \\
\hline 2009 & 1.51 & 27.03 & 2.76 & 831.33 & 409.27 \\
\hline 2010 & 1.51 & 27.12 & 2.75 & 781.62 & 384.80 \\
\hline 2011 & 1.51 & 27.13 & 2.74 & 754.17 & 371.28 \\
\hline 2012 & 1.51 & 27.09 & 2.72 & 726.60 & 357.71 \\
\hline 2013 & 1.51 & 27.00 & 2.69 & 697.83 & 343.55 \\
\hline 2014 & 1.50 & 26.87 & 2.66 & 668.94 & 329.32 \\
\hline 2015 & 1.50 & 26.69 & 2.62 & 639.55 & 314.85 \\
\hline 2016 & 1.49 & 26.48 & 2.58 & 610.54 & 300.57 \\
\hline 2017 & 1.48 & 26.24 & 2.54 & 582.34 & 286.69 \\
\hline 2018 & 1.46 & 25.97 & 2.49 & 555.75 & 273.60 \\
\hline 2019 & 1.45 & 25.69 & 2.45 & 528.70 & 260.28 \\
\hline 2020 & 1.43 & 25.41 & 2.40 & 501.18 & 246.74 \\
\hline 2021 & 1.42 & 25.13 & 2.35 & 477.56 & 235.11 \\
\hline 2022 & 1.40 & 24.85 & 2.30 & 455.48 & 224.24 \\
\hline 2023 & 1.39 & 24.58 & 2.26 & 435.22 & 214.26 \\
\hline 2024 & 1.37 & 24.31 & 2.21 & 416.87 & 205.23 \\
\hline 2025 & 1.36 & 24.05 & 2.17 & 400.30 & 197.07 \\
\hline 2026 & 1.35 & 23.80 & 2.13 & 386.49 & 190.27 \\
\hline 2027 & 1.33 & 23.57 & 2.10 & 374.48 & 184.36 \\
\hline 2028 & 1.32 & 23.37 & 2.06 & 364.14 & 179.27 \\
\hline 2029 & 1.31 & 23.20 & 2.03 & 355.36 & 174.95 \\
\hline 2030 & 1.31 & 23.07 & 2.01 & 347.95 & 171.30 \\
\hline Period & \multicolumn{5}{|c|}{ Cumulative Totals } \\
\hline $1990-2000$ & 14.42 & 257.70 & 27.09 & $9,628.52$ & $4,740.19$ \\
\hline $1990-2010$ & 29.09 & 520.69 & 54.27 & $18,411.16$ & $9,063.95$ \\
\hline $1990-2020$ & 43.93 & 785.28 & 80.16 & $24,676.75$ & $12,148.56$ \\
\hline $1990-2030$ & 57.48 & 1025.2 & 101.79 & $28,690.61$ & $14,124.61$ \\
\hline
\end{tabular}


TABLE 16 Oil Displacement by Light-Duty Vehicle Technology

\begin{tabular}{|c|c|c|c|c|c|c|c|}
\hline \multirow[b]{2}{*}{ Year } & \multicolumn{7}{|c|}{ Oil Displacement $\left(10^{6} \mathrm{bbl} / \mathrm{day}\right)$} \\
\hline & FFV $^{\mathrm{a}}$ & Hybrid & $\begin{array}{l}\text { Electric } \\
\text { Vehicle } \\
\end{array}$ & $\begin{array}{c}\text { CNG }^{b} \\
\text { LPG }\end{array}$ & Alcohols & $\begin{array}{c}\text { Fuel } \\
\text { Cell } \\
\end{array}$ & Total \\
\hline 1990 & 0 & 0 & 0 & 0 & 0 & 0 & 0 \\
\hline 1991 & 0 & 0 & 0 & 0 & 0 & 0 & 0 \\
\hline 1992 & 0 & 0 & 0 & 0 & 0 & 0 & 0 \\
\hline 1993 & 0 & 0 & 0 & 0 & 0 & 0 & 0 \\
\hline 1994 & 0 & 0 & 0 & 0 & 0 & 0 & 0 \\
\hline 1995 & 0 & 0 & 0 & 0.01 & 0 & 0 & 0.01 \\
\hline 1996 & 0 & 0 & 0 & 0.01 & 0 & 0 & 0.01 \\
\hline 1997 & 0 & 0 & 0 & 0.03 & 0 & 0 & 0.03 \\
\hline 1998 & 0 & 0 & 0 & 0.04 & 0 & 0 & 0.04 \\
\hline 1999 & 0 & 0 & 0 & 0.06 & 0 & 0 & 0.06 \\
\hline 2000 & 0 & 0 & 0 & 0.08 & 0 & 0 & 0.08 \\
\hline 2001 & 0 & 0 & 0.01 & 0.10 & 0 & 0 & 0.10 \\
\hline 2002 & 0 & 0 & 0.01 & 0.12 & 0 & 0 & 0.13 \\
\hline 2003 & 0 & 0.01 & 0.02 & 0.14 & 0.01 & 0 & 0.17 \\
\hline 2004 & 0 & 0.03 & 0.02 & 0.17 & 0.01 & 0 & 0.23 \\
\hline 2005 & 0 & 0.06 & 0.03 & 0.19 & 0.03 & 0 & 0.31 \\
\hline 2006 & 0 & 0.11 & 0.04 & 0.22 & 0.04 & 0 & 0.41 \\
\hline 2007 & 0.01 & 0.17 & 0.05 & 0.25 & 0.06 & 0.01 & 0.55 \\
\hline 2008 & 0.05 & 0.25 & 0.05 & 0.28 & 0.10 & 0.02 & 0.75 \\
\hline 2009 & 0.13 & 0.33 & 0.06 & 0.32 & 0.20 & 0.03 & 1.07 \\
\hline 2010 & 0.34 & 0.43 & 0.06 & 0.36 & 0.42 & 0.05 & 1.65 \\
\hline 2011 & 0.38 & 0.52 & 0.07 & 0.39 & 0.48 & 0.06 & 1.91 \\
\hline 2012 & 0.43 & 0.61 & 0.08 & 0.43 & 0.55 & 0.08 & 2.18 \\
\hline 2013 & 0.49 & 0.71 & 0.08 & 0.46 & 0.62 & 0.10 & 2.46 \\
\hline 2014 & 0.54 & 0.80 & 0.08 & 0.49 & 0.69 & 0.13 & 2.74 \\
\hline 2015 & 0.60 & 0.89 & 0.09 & 0.53 & 0.77 & 0.15 & 3.02 \\
\hline 2016 & 0.65 & 0.97 & 0.09 & 0.56 & 0.84 & 0.18 & 3.30 \\
\hline 2017 & 0.70 & 1.06 & 0.10 & 0.59 & 0.90 & 0.22 & 3.56 \\
\hline 2018 & 0.73 & 1.13 & 0.10 & 0.62 & 0.95 & 0.26 & 3.79 \\
\hline 2019 & 0.75 & 1.21 & 0.11 & 0.65 & 1.00 & 0.31 & 4.02 \\
\hline 2020 & 0.78 & 1.29 & 0.11 & 0.68 & 1.05 & 0.36 & 4.26 \\
\hline 2021 & 0.80 & 1.35 & 0.12 & 0.70 & 1.08 & 0.41 & 4.46 \\
\hline 2022 & 0.82 & 1.41 & 0.13 & 0.72 & 1.13 & 0.45 & 4.66 \\
\hline 2023 & 0.85 & 1.45 & 0.13 & 0.74 & 1.17 & 0.50 & 4.84 \\
\hline 2024 & 0.87 & 1.49 & 0.14 & 0.75 & 1.21 & 0.55 & 5.01 \\
\hline 2025 & 0.89 & 1.53 & 0.14 & 0.77 & 1.25 & 0.59 & 5.17 \\
\hline 2026 & 0.91 & 1.56 & 0.14 & 0.77 & 1.28 & 0.63 & 5.29 \\
\hline 2027 & 0.92 & 1.58 & 0.15 & 0.78 & 1.31 & 0.67 & 5.41 \\
\hline 2028 & 0.93 & 1.60 & 0.15 & 0.78 & 1.34 & 0.71 & 5.51 \\
\hline 2029 & 0.94 & 1.61 & 0.16 & 0.78 & 1.37 & 0.75 & 5.60 \\
\hline 2030 & 0.94 & 1.62 & 0.16 & 0.78 & 1.39 & 0.78 & 5.68 \\
\hline Period & \multicolumn{7}{|c|}{ Cumulative Totals } \\
\hline $1990-2000$ & 0.00 & 0.00 & 0.01 & 0.22 & 0.00 & 0.00 & 0.23 \\
\hline $1990-2010$ & 0.54 & 1.39 & 0.36 & 2.37 & 0.87 & 0.10 & 5.61 \\
\hline $1990-2020$ & 6.60 & 10.57 & 1.27 & 7.76 & 8.69 & 1.96 & 36.84 \\
\hline $1990-2030$ & 15.46 & 25.77 & 2.68 & 15.34 & 21.24 & 8.00 & 88.48 \\
\hline
\end{tabular}

a $F F V=$ Flexible-fuel vehicle.

b CNG/LPG = Compressed natural gas and liquid petroleum gas (propane). 
TABLE 17 Baseline Oil Consumed and Displaced by All Advanced Technologies

\begin{tabular}{|c|c|c|c|c|c|c|c|}
\hline \multirow[b]{3}{*}{ Year } & \multicolumn{5}{|c|}{ Baseline Forecasts $^{a}$} & \multirow{2}{*}{\multicolumn{2}{|c|}{$\begin{array}{l}\text { Percent Displaced by } \\
\text { Advanced Technologies }\end{array}$}} \\
\hline & \multicolumn{2}{|c|}{ Gasoline Consumption } & \multirow[b]{2}{*}{$\begin{array}{l}\text { Transportation Oil } \\
\left(10^{6} \mathrm{bbl} / \mathrm{day}\right)\end{array}$} & \multirow[b]{2}{*}{$\begin{array}{c}\text { U.S. Oil } \\
\left(10^{6} \mathrm{bbl} / \mathrm{day}\right)\end{array}$} & \multirow[b]{2}{*}{$\begin{array}{l}\text { Highway Oil } \\
\left(10^{6} \mathrm{bbl} / \mathrm{day}\right)\end{array}$} & & \\
\hline & Quads & $10^{6} \mathrm{bbl} / \mathrm{day}$ & & & & Gasoline & $\begin{array}{l}\text { Transport- } \\
\text { ation Oil }\end{array}$ \\
\hline 1990 & 13.59 & 6.42 & 11.04 & 16.99 & 7.78 & 4.0 & 2.2 \\
\hline 1991 & 13.65 & 6.45 & 11.03 & 25.32 & 7.78 & 3.5 & 2.3 \\
\hline 1992 & 13.70 & 6.47 & 11.02 & 33.65 & 7.79 & 3.8 & 2.4 \\
\hline 1993 & 13.90 & 6.56 & 11.25 & 31.86 & 7.95 & 4.1 & 2.4 \\
\hline 1994 & 14.09 & 6.66 & 11.49 & 30.08 & 8.10 & 4.3 & 2.5 \\
\hline 1995 & 14.29 & 6.75 & 11.72 & 28.29 & 8.25 & 4.6 & 2.6 \\
\hline 1996 & 14.48 & 6.84 & 11.95 & 26.50 & 8.41 & 5.0 & 2.8 \\
\hline 1997 & 14.68 & 6.93 & 12.19 & 24.72 & 8.56 & 5.4 & 3.0 \\
\hline 1998 & 14.87 & 7.02 & 12.42 & 22.93 & 8.71 & 5.9 & 3.2 \\
\hline 1999 & 15.07 & 7.12 & 12.66 & 21.14 & 8.86 & 6.4 & 3.5 \\
\hline 2000 & 15.26 & 7.21 & 12.89 & 19.36 & 9.02 & 6.9 & 3.7 \\
\hline 2001 & 15.39 & 7.27 & 13.07 & 19.57 & 9.12 & 7.4 & 4.1 \\
\hline 2002 & 15.53 & 7.33 & 13.24 & 19.77 & 9.23 & 8.0 & 4.6 \\
\hline 2003 & 15.66 & 7.40 & 13.41 & 19.98 & 9.33 & 8.8 & 5.0 \\
\hline 2004 & 15.80 & 7.46 & 13.59 & 20.19 & 9.44 & 9.7 & 5.4 \\
\hline 2005 & 15.93 & 7.52 & 13.76 & 20.40 & 9.54 & 11.0 & 5.8 \\
\hline 2006 & 16.03 & 7.57 & 13.92 & 20.57 & 9.64 & 12.1 & 7.1 \\
\hline 2007 & 16.13 & 7.62 & 14.08 & 20.75 & 9.73 & 13.6 & 8.3 \\
\hline 2008 & 16.24 & 7.67 & 14.24 & 20.92 & 9.83 & 15.6 & 9.5 \\
\hline 2009 & 16.34 & 7.72 & 14.40 & 21.09 & 9.92 & 18.4 & 10.8 \\
\hline 2010 & 16.44 & 7.77 & 14.56 & 21.27 & 10.02 & 22.8 & 12.0 \\
\hline 2011 & 16.55 & 7.82 & 14.73 & 21.45 & 10.12 & 25.2 & 13.3 \\
\hline 2012 & 16.76 & 7.91 & 15.07 & 21.81 & 10.32 & 27.6 & 14.5 \\
\hline 2013 & 16.86 & 7.96 & 15.24 & 21.99 & 10.42 & 30.1 & 15.9 \\
\hline 2014 & 16.97 & 8.01 & 15.41 & 22.17 & 10.52 & 32.5 & 17.1 \\
\hline 2015 & 17.07 & 8.06 & 15.58 & 22.35 & 10.62 & 35.0 & 18.4 \\
\hline 2016 & 17.18 & 8.11 & 15.75 & 22.53 & 10.72 & 37.4 & 19.7 \\
\hline 2017 & 17.28 & 8.16 & 15.92 & 22.71 & 10.82 & 39.6 & 20.9 \\
\hline 2018 & 17.39 & 8.21 & 16.09 & 22.89 & 10.92 & 41.8 & 22.0 \\
\hline 2019 & 17.49 & 8.26 & 16.25 & 23.07 & 11.02 & 43.9 & 23.1 \\
\hline 2020 & 17.60 & 8.31 & 16.42 & 23.25 & 11.12 & 46.0 & 24.2 \\
\hline 2021 & 17.70 & 8.37 & 16.59 & 23.43 & 11.22 & 47.8 & 25.2 \\
\hline 2022 & 17.81 & 8.42 & 16.76 & 23.61 & 11.32 & 49.4 & 26.1 \\
\hline 2023 & 17.91 & 8.48 & 16.93 & 23.79 & 11.42 & 50.9 & 26.8 \\
\hline 2024 & 18.02 & 8.53 & 17.10 & 23.97 & 11.52 & 52.3 & 27.6 \\
\hline 2025 & 18.12 & 8.59 & 17.27 & 24.15 & 11.62 & 53.5 & 28.2 \\
\hline 2026 & 18.23 & 8.64 & 17.44 & 24.33 & 11.72 & 54.5 & 28.7 \\
\hline 2027 & 18.33 & 8.70 & 17.61 & 24.51 & 11.82 & 55.3 & 29.1 \\
\hline 2028 & 18.44 & 8.75 & 17.78 & 24.70 & 11.92 & 56.0 & 29.5 \\
\hline 2029 & 18.55 & 8.80 & 17.95 & 24.88 & 12.02 & 56.6 & 29.8 \\
\hline 2030 & 18.65 & 8.86 & 18.12 & 25.06 & 12.12 & 57.1 & 30.1 \\
\hline Period & & & Cumulative Tota & & & & \\
\hline $1990-2000$ & 157.56 & 74.42 & 129.66 & 280.84 & 91.21 & & \\
\hline $1990-2010$ & 317.05 & 149.76 & 267.94 & 485.35 & 187.01 & & \\
\hline $1990-2020$ & 488.18 & 230.60 & 424.39 & 709.56 & 293.61 & & \\
\hline $1990-2030$ & 669.95 & 316.74 & 597.95 & 952.00 & 410.33 & & \\
\hline
\end{tabular}

a Baseline consumption before the introduction of advanced technologies. Derived from DOE/EIA 1994. 


\section{REFERENCES}

Davis, S., and S. Strang, 1993; Transportation Energy Data Book, Edition 13, Oak Ridge National Laboratory report ORNL-6743, March.

DeLuchi, M.A., 1991, Emissions of Greenhouse Gases from the Use of Transportation Fuels and Electricity, Vol. 1: Main Text, Argonne National Laboratory report ANL/ESD/TM-22, Nov.

Fulton, L., 1991, Alternative Vehicle Sales Module: Design of the Modelling Framework and Prototype Module Description, U.S. Department of Energy, Energy Information Administration, Sept.

Greene, D., and A. Rathi, 1990, Alternative Motor Fuel Use Model - Model Theory and Design and User's Guide, Oak Ridge National Laboratory report ORNL/TM-11448, March.

Mintz, M., A. Vyas, and L. Conley, 1993, Differences Between EPA-Test and In-Use Fuel Economy: Are the Correction Factors Correct?, Transportation Research Board, Transportation Research Record 1416.

U.S. DOC: See U.S. Department of Commerce.

U.S. DOE: See U.S. Department of Energy.

U.S. Department of Commerce, 1987 Truck Inventory and Use Survey, Bureau of the Census, public use data tape.

U.S. Department of Energy, 1994a, Five-Year Transportation Program Plan, 1994, Office of Transportation Programs, Aug. 1.

U.S. Department of Energy, 1994b, Annual Energy Outlook, 1994, Energy Information Administration, DOE/EIA-0383(94), Jan.

Wang, Q., and D. Santini, 1993, Magnitude and Value of Electric Vehicle Emissions Reductions for Six Driving Cycles in Four U.S. Cities with Varying Air Quality Problems, Transportation Research Board, Transportation Research Record 1416. 


\section{APPENDIX: "READ ME" FILE}

IMPACTT (Integrated Market Penetration and Anticipated Cost of Transportation Technologies) was developed by Argonne National Laboratory's Center for Transportation Research to assist the U.S. Department of Energy's Office of Transportation Technologies (OTT) with program planning and development. Written in EXCEL 5.0 workbook format, IMPACTT is a spreadsheet model operating in either an Apple or PC/Windows environment. The current version consists of 16 worksheets - eight of them apply to all technologies (i.e., general worksheets); the other eight are specific to a particular technology or fuel alternative. The general worksheets are called INPUTS, SALES-MPG, EMIS INPUTS, VMT SUM, OIL SUM, EMIS SUM, EMIS RED SUM, and CON SUM.

\section{GENERAL WORKSHEETS}

To estimate the number of new advanced-technology vehicles on the road in a given year, market-penetration rates must be combined with an external forecast of new-vehicle sales by vehicle type, and vehicles must be tracked through a survival or vintaging procedure. The INPUTs worksheet contains user-supplied forecasts of market penetration and marginal cost for each advanced technology under examination and an emissions reduction value for each of three criteria pollutants $\left(\mathrm{NO}_{\mathrm{x}}, \mathrm{CO}\right.$, and $\left.\mathrm{NMHC}\right)$. Each advanced technology contained on the INPUTS worksheet must have a technology-specific worksheet associated with it.

The SALES-MPG worksheet converts user-supplied forecasts of auto and light-truck sales and fuel economy into weighted averages for input into the stock model and calculations of oil displacement and fuel substitution. Note that users can input either EPA-test or estimated on-the-road fuel economy. Default forecasts of sales and EPA-test fuel economy were extrapolated from those in the 1994 Annual Energy Outlook (DOE/EIA 1994). Default estimates of on-the-road fuel economy assume a $20 \%$ shortfall or gap from EPA test results, which are the default inputs (Mintz, Vyas, and Conley 1993).

The EMIS INPUTS worksheet contains default tailpipe emission rates by engine type and vintage and refinery and power-plant emission rates by fuel type. Expressed in g/mi, rates were computed from the EPA's MOBILE5a model. Within EMIS INPUTS, values for total light-duty vehicles are weighted as $60 \%$ autos and $40 \%$ light trucks. Default values for power-plant emissions are based on the year 2000 generation mix for New York City and southern California, the two locations likely to see the earliest EV market penetration. Default values are weighted by the relative share of VMT contributed by each of these two markets (Wang and Santini 1994).

Four of the general worksheets aggregate results across the technology-specific worksheets. The VMT SUM worksheet summarizes stocks and vehicle-miles displaced by all advanced-technology vehicles, while OIL SUM and EMIS RED SUM summarize total oil displacement and emissions reduction. Substitution-fuel use, again aggregated over all technologies considered in the particular scenario under examination, is summarized in the 
CON SUM worksheet. For all four of these worksheets, results are reported annually for 1990-2030 and cumulatively (as appropriate) for 1990-2000, 1990-2010, 1990-2020 and 1990-2030. Outputs include advanced-technology vehicles on the road, oil displacement, VMT displacement, emissions reduction, value of emissions reduction, substitution-fuel use, and fleet-average fuel economy (miles/gallon gasoline equivalent) for the fleet of advancedtechnology vehicles on the road.

\section{Technology-Specific Worksheets}

IMPACTT operates on a set of assumptions that define a particular scenario. The diversified scenario developed by DOE's Office of Transportation Technologies for its five-year program plan is the default case contained in the workbook file. That scenario required the use of eight technology-specific worksheets: HYBRID, ELECTRIC, FUEL CELL, FLEX ETHANOL, DED ETHANOL, CNG, LPG, and ICE. Thus, the default version of the model can accommodate up to eight different technologies.

Chief among the parameters used to define a particular scenario is the market penetration of the various advanced technologies - these rates are, in turn, a key component of the vehicle stock calculation. The default assumption in IMPACTT is that advancedtechnology vehicles replace conventional vehicles on a one-for-one basis. The only exception is for advanced-battery electric vehicles, which are assumed to have a small (i.e., 10\% of all electric vehicle sales), unique market demand. Thus, EV market penetration is multiplied by 0.9 in the default case, and EV electricity use is divided by 0.9 to account for unique or nonreplacement market demand.

The USAGE module estimates VMT per year as a function of vehicle age. The key parameters, miles per year for a new vehicle and a degradation rate, are the same for most light-duty-vehicle technologies. The key exception is the assumption of reduced miles-peryear by vehicle age for electric vehicles, which is embedded into the usage model calculation.

Several technology-specific parameters may be user-defined. These include gasolineequivalent fuel economy, Btu content of the alternative fuel relative to gasoline, and efficiency relative to a conventionally fueled vehicle, all of which are used to compute fuel substitution (i.e., alternative-fuel use). For flex-fueled vehicles, five additional parameters are included in the calculation: alcohol share of reformulated gasoline, ethanol and methanol shares of fuel use, and ethanol and methanol fuel use. In the current version of IMPACTT, ethanol and methanol shares are estimated from an exogenous biofuels production forecast and an assumed split between bioethanol and biomethanol production. The default production forecast (contained in cells AO-13 through AV-57 of the DED ETOH worksheet) was developed by the Office of Transportation Technologies for its draft program plan. It assumes declining real prices for biofuels along with ethanol accounting for $100 \%$ of biofuels production. Thus, the default forecast assumes that ethanol shares are supply-constrained to the sum of current and new production capacity. Because the Office of Transportation Technologies has no ongoing methanol program, flex-fuel methanol and dedicated methanol vehicles are not modeled on the default file. 
For electric vehicles, three additional parameters may be user defined. Annual usage may be set equal to that of conventional vehicles or modified to account for range limitations and differences in life expectancy. In the default case, electric vehicles are assumed to experience two-thirds the usage of conventional vehicles at all ages. Distribution and transmission efficiencies (cells Z12 and AA12 of the ELEC worksheet), which are used to account for losses between the power plant and vehicle, may also be user-defined. In the default case, $90 \%$ is assumed for distribution efficiency, and $95 \%$ is assumed for transmission efficiency. Note that calculations go back no further in the fuel cycle than the plant gate. In other words, fuel conversion efficiencies (e.g., to produce electricity or fuel-grade alcohol, or to compress natural gas) are not included in the current fuel substitution calculation. Total fuel-cycle energy use and emissions will be added to a subsequent version of IMPACTT. 
